\title{
ALKI signalling analysis identifies angiogenesis related genes and reveals disparity between TGF- $\beta$ and constitutively active receptor induced gene expression
}

\author{
Andreas Lux*1,2, Fiona Salway³, Holly K Dressman4,5, Gabriele Kröner-Lux ${ }^{6}$, \\ Mathias Hafner ${ }^{2}$, Philip JR Day ${ }^{3}$, Douglas A Marchuk ${ }^{4}$ and John Garland ${ }^{7}$
}

\begin{abstract}
Address: ${ }^{1}$ University Hospital Mannheim, 68167 Mannheim, University of Applied Sciences Mannheim, Windeckstr. 110, 68163 Mannheim, Germany, 2Institute of Molecular and Cell Biology, University of Applied Sciences Mannheim, Windeckstr. 110, 68163 Mannheim, Germany, ${ }^{3}$ Centre for Integrated Genomic Medical Research, University of Manchester, Manchester, M13 9PT, UK, ${ }^{4}$ Department of Molecular Genetics and Microbiology, DUMC, Durham, NC 27710, USA, 50 Duke Institute for Genome Sciences and Policy, DUMC, Durham, NC 27710, USA, 6 PROGEN Biotechnik GmbH, Maasstr. 30, 69123 Heidelberg, Germany and ${ }^{7}$ Manchester Cardiovascular Research Group, University of Manchester, Department of Medicine, M13 9WL, UK

Email: Andreas Lux* - a.lux@hs-mannhei.de; Fiona Salway - Fiona.Salway@man.ac.uk; Holly K Dressman - dress002@mc.duke.edu; Gabriele Kröner-Lux - kroener-lux@progen.de; Mathias Hafner - m.hafner@hs-mannheim.de; Philip JR Day - philip.j.day@man.ac.uk; Douglas A Marchuk - march004@mc.duke.edu; John Garland - john.m.garland@man.ac.uk

* Corresponding author
\end{abstract}

Published: 04 April 2006

BMC Cardiovascular Disorders 2006, 6:13 doi:10.1/86/147|-2261-6-13
Received: 21 December 2005

Accepted: 04 April 2006

This article is available from: http://www.biomedcentral.com/I47I-226I/6/13

(c) 2006 Lux et al; licensee BioMed Central Ltd.

This is an Open Access article distributed under the terms of the Creative Commons Attribution License (http://creativecommons.org/licenses/by/2.0), which permits unrestricted use, distribution, and reproduction in any medium, provided the original work is properly cited.

\begin{abstract}
Background: TGF- $\beta$ I is an important angiogenic factor involved in the different aspects of angiogenesis and vessel maintenance. TGF- $\beta$ signalling is mediated by the T $\beta$ RII/ALK5 5 receptor complex activating the Smad2/Smad3 pathway. In endothelial cells TGF- $\beta$ utilizes a second type I receptor, ALKI, activating the SmadI/Smad5 pathway. Consequently, a perturbance of ALKI, ALK5 or T $\beta R$ II activity leads to vascular defects. Mutations in ALKI cause the vascular disorder hereditary hemorrhagic telangiectasia (HHT).

Methods: The identification of ALKI and not ALK5 regulated genes in endothelial cells, might help to better understand the development of HHT. Therefore, the human microvascular endothelial cell line HMEC-I was infected with a recombinant constitutively active ALKI adenovirus, and gene expression was studied by using gene arrays and quantitative real-time PCR analysis.

Results: After 24 hours, 34 genes were identified to be up-regulated by ALKI signalling. Analysing ALKI regulated gene expression after 4 hours revealed 13 genes to be up- and 2 to be down-regulated. Several of these genes, including IL-8, ET-I, IDI, HPTP $\eta$ and TEAD4 are reported to be involved in angiogenesis. Evaluation of ALKI regulated gene expression in different human endothelial cell types was not in complete agreement. Further on, disparity between constitutively active ALKI and TGF- $\beta$ I induced gene expression in HMEC-I cells and primary HUVECs was observed.

Conclusion: Gene array analysis identified 49 genes to be regulated by ALKI signalling and at least 14 genes are reported to be involved in angiogenesis. There was substantial agreement between the gene array and quantitative real-time PCR data. The angiogenesis related genes might be potential HHT modifier genes. In addition, the results suggest endothelial cell type specific ALKI and TGF- $\beta$ signalling.
\end{abstract}




\section{Background}

Vascular development and homeostasis are regulated by a number of cytokines including members of the transforming growth factor-beta (TGF- $\beta$ ) superfamily that resemble a group of structurally related secreted polypeptides that regulate numerous cellular activities including proliferation, differentiation, migration, extracellular matrix deposition and apoptosis $[1,2]$. This family consists of over 35 cytokines that include TGF- $\beta 1,-\beta 2$ and $-\beta 3$, as well as activins, inhibins, nodals and the large group of bone morphogenetic proteins (BMPs). All have crucial roles in development and tissue homeostasis and their importance is further demonstrated by their involvement in different diseases $[1,3]$.

Signalling is mediated by a class of single transmembrane domain serine/threonine kinase receptors, types -I and -II, that initiate phosphorylation of co-transcription factors of the Smad protein family $[2,4]$. There are five type II receptors and 7 type I receptors designated as activin receptorlike kinases (ALKs), ALK1-7. Ligand binding induces complex formation between type I and type II receptors, upon which the constitutively active kinase of the type II receptor phosphorylates the type I receptor in its so called 'GS' domain. Activated type I receptor in turn phosphorylates receptor-regulated Smads (R-Smads; Smad-1, -2, -3, -5 and -8 ), which bind to the Smad4 protein, translocate to the nucleus and regulate gene expression in concert with other transcription factors. A third class of Smads, the inhibitory Smads (I-Smads; Smad-6 and -7), oppose the signalling activity of R-Smads and Smad4 by different mechanisms. Each TGF- $\beta$ family member binds to a characteristic set of type I and II receptors and based on this combination activates a specific R-Smad.

In angiogenesis the formation of new blood vessels by denovo capillary development from pre-existing vascular endothelium, vessel assembly, maturation and remodelling is based on a finely balanced series of events in which TGF- $\beta$ plays a pivotal role, both as a pro-angiogenic (activation phase) as well as an anti-angiogenic (resolutionmaintenance phase) cytokine $[5,6]$. This bi-phasic activity is dose-dependent $[7,8]$. Many angiogenic disorders most likely result from an unbalanced activity or loss of different angiogenic factors. Hereditary hemorrhagic telangiectasia (HHT) is characterized by telangiectases and arteriovenous malformations (AVMs) typically found in the skin and mucocutaneous tissues [9-11]. Telangiectases and AVMs show abnormal connection between arteries and veins that is devoid of intervening capillaries and has a more vein-like phenotype [12]. Previous studies have shown that HHT is caused by mutations in either endoglin (CD105) or ALK1 [13,14]. More recently, mutations in Smad4 were reported to cause a syndrome consisting of both juvenile polyposis and hereditary haemorrhagic telangiectasia phenotypes [15].

Endoglin binds TGF- $\beta 1$ and $-\beta 3$ isoforms that requires presence of the TGF- $\beta$ type II receptor $[16,17]$. ALK1, a type I receptor for TGF- $\beta 1$ and $-\beta 3[6,18]$, activates the BMP signalling pathway by phosphorylating Smad1/5 $[19,20]$. Both endoglin and ALK1 are predominantly expressed by endothelial cells. Studies with mice have shown that a homozygous knock-out of either endoglin or ALK1 is embryonically lethal due to vascular defects [21-25]. Heterozygous endoglin as well as ALK1 mice are viable, but a percentage of those develop a phenotype similar to that observed in HHT patients $[25,26]$.

Recent studies in endothelial cells have shown that TGF- $\beta$ signals through ALK1, activating the Smad1/5 pathway, and through ALK5, activating the Smad2/3 pathway [6]. These two pathways have in a dose-dependent manner opposing effects on endothelial cell behaviour: ALK1 promotes cell proliferation and migration, whereas ALK5 inhibits both processes. Low TGF- $\beta$ concentrations induce ALK1 signalling, which needs and is promoted by endoglin $[27,28]$ and in addition requires the presence of ALK5 [29]. In contrast, high TGF- $\beta$ concentrations activate the ALK5 pathway.

The lethality of endoglin or ALK1 deletion in mice points to essential roles for both in normal and aberrant angiogenesis but their exact roles are still largely unknown. To understand the function of endoglin and ALK1 in these processes requires elucidation of their activities in cell adhesion, migration, and importantly gene regulation. Gene arrays can simultaneously examine many hundreds or thousands of genes but suffer from being only semiquantitative. Also, many changes are difficult to decipher due to high background that makes interpretation uncertain. Quantitative real-time (qRT)-PCR sensitively detects quantitative changes in mRNA but cannot process similarly large numbers of genes

In order to identify target genes specific to ALK1 signalling, we over-expressed ALK1 in the human microvascular endothelial cell line HMEC-1 using recombinant adenovirus carrying a constitutively active form of ALK1, thus masking ALK5 responses. We then compared gene array hybridisation data representing 5,600 human full-length genes, with semi-quantitative and qRT-PCR analyses of transcripts identified as altered by the Affymetrix GeneChip $^{\mathrm{TM}}$ arrays. We found 34 genes to be up-regulated by constitutively active ALK1 signalling after 24 hours and 15 genes being dys-regulated (13 up- and 2 down-regulated) after 4 hours. Consistent with the vascular disorder HHT, at least 14 of the ALK1 response genes are reported to be involved in angiogenesis, vascular disorders or the home- 
ostasis of the vascular system. We found substantial agreement between the gene array and qRT-PCR data, but there were a number of disparate results regarding TGF- $\beta$ induced signalling and constitutively active receptor signalling depending on the endothelial cell type.

\section{Methods \\ Cell culture and growth factor}

HMEC-1 cell line (derived from human dermal microvascular endothelial cells) [30] was cultured in MCDB-131 containing $15 \%$ human serum, penicillin $(100 \mathrm{U} / \mathrm{ml})$, and streptomycin $(100 \mu \mathrm{g} / \mathrm{ml})$. ECRF24 cell line (derived from human umbilical vein endothelial cells) [31] was cultured in equal volumes of M199 and RPMI 1640 medium containing $2 \mathrm{mM}$ glutamine, penicillin $(100 \mathrm{U} /$ $\mathrm{ml})$, streptomycin $(100 \mu \mathrm{g} / \mathrm{ml}), \mathrm{G} 418(100 \mu \mathrm{g} / \mathrm{ml})$, and $20 \%$ human serum. Primary human umbilical cord vein endothelial cells (HUVECs) were cultured in M199 glutamax containing HEPES $(16 \mathrm{mM})$, heparin $(6.4 \mathrm{U} /$ $\mathrm{ml})$, gentamicin $(80 \mu \mathrm{g} / \mathrm{ml})$, PD-ECGF $(20 \mu \mathrm{g} / \mathrm{ml}), 10 \%$ foetal calf serum (FCS) and 10\% human serum. Cre8 cells and HEK 293A cells were cultured in Dulbecco's modified Eagle's medium with $10 \%$ FCS, penicillin $(100 \mathrm{U} / \mathrm{ml})$, and streptomycin $(100 \mu \mathrm{g} / \mathrm{ml})$. All cells were cultured at $37^{\circ} \mathrm{C}$ in a humidified atmosphere of air containing $5 \%$ $\mathrm{CO}_{2}$. Media, media supplements and FCS were obtained from PAA Laboratories (Germany) and Invitrogen (Germany). TGF- $\beta 1$ and PD-ECGF were obtained from R\&D Systems (Wiesbaden, Germany).

\section{Recombinant adenovirus}

The cDNA for constitutively active ALK1 (ALK1QD-HA, Cterminal HA tagged) was subcloned into the HindIII/ BamHI sites of the Adlox vector, which possesses one loxP site, a left inverted terminal repeat followed by a packaging sequence $(\varnothing)$, the human cytomegalovirus immediate-early promoter, a multiple cloning site, and a right inverted terminal repeat. The Adlox vector serves as the shuttle vector for generating recombinant adenovirus via the Cre-lox system [32]. Using $\mathrm{CaPO}_{4}$, Cre8 cells were cotransfected with the AdLox-ALK1QD plasmid DNA (2.1 $\mu \mathrm{g})$ and DNA $(2.1 \mu \mathrm{g})$ of the E1-deleted $\phi 5$ virus (adenovirus type 5 engineered with two lox-P sites flanking the packaging site), creating the AdALK1 $\mathrm{QD}$ virus. For control infections virus containing no insert (AdCMV3) was created in addition to a virus expressing the bacterial $\beta$-galactosidase gene named AdLacZ. Following amplification of the recombinant virus in Cre8 cells, a large-scale virus preparation was made from infected HEK 293A cells. The cells were harvested 2 days after infection, sedimented $(1000 \times \mathrm{g}, 10 \mathrm{~min})$ and the cell pellet was resuspended in $10 \mathrm{ml}$ of OPTI-MEM (Gibco-BRL), freeze-thawed three times, and resedimented. The resulting lysate $(\sim 10 \mathrm{ml})$ was loaded onto a two-step $\mathrm{CsCl}$ gradient $(10 \mathrm{ml}$ of $\mathrm{CsCl}$ at $1.4 \mathrm{~g} / \mathrm{cm}^{3}$ overlaid with $10 \mathrm{ml}$ of $\mathrm{CsCl}$ at $1.2 \mathrm{~g} / \mathrm{cm}^{3}$, and the gradient was centrifuged $\left(20,000 \mathrm{rpm}, 2 \mathrm{hr}, 15^{\circ} \mathrm{C}\right.$, SW2 8 rotor). Viral particles in the $1.3 \mathrm{~g} / \mathrm{cm}^{3}$ region were harvested and the volume was brought to $21 \mathrm{ml}$ with a solution of $1.3 \mathrm{~g} / \mathrm{cm}^{3} \mathrm{CsCl}$. In a tube the viral solution was overlaid onto a cushion of $1.5 \mathrm{ml}$ of $1.5 \mathrm{~g} / \mathrm{cm}^{3} \mathrm{CsCl}$ solution, and centrifuged $\left(40,000 \mathrm{rpm}, 12-16 \mathrm{hr}, 15^{\circ} \mathrm{C}\right.$ in an SW41 rotor). The resulting viral band $(1.5-2.5 \mathrm{ml})$ was harvested and dialyzed at $4^{\circ} \mathrm{C}$ three times against 1 litre of buffer using a Slide-A-Lyzer (Pierce Chemical, Indianapolis, IN) and storage buffer (10 mM Tris-HCl, pH 7.4, 0.9\% $\mathrm{NaCl}, 1 \mathrm{mM} \mathrm{MgCl}_{2}, 1 \mathrm{mM} \mathrm{CaCl}_{2}$, with $10 \%$ glycerol in the last change) then aliquoted and stored at $-80^{\circ} \mathrm{C}$. Stock concentrations (viral particles [vp] per $\mathrm{ml}$ ) were calculated from $\mathrm{OD}_{260} \times$ dilution $\times 1.1 \times 10^{12}$, with $\mathrm{OD}_{260 / 280}$ of 1.2 1.3 .

\section{Viral infection}

In order to test whether HMEC-1 cells can be infected by adenovirus, cells were incubated with AdLacZ at different multiplicity of infection (MOIs). An MOI of 50 was established to be optimal for $100 \%$ infection efficiency demonstrated by X-Gal staining (data not shown). Further on, an MOI of 50 displayed no effect on cell growth or morphology when tested for AdLacZ, AdCMV3 and more important for AdALK1QD, whereas MOIs of $>100$ affected cellular growth and induced partial cell death for all three tested recombinant adenoviruses. Once optimal MOI was established endothelial cells were seeded into a $100 \mathrm{~mm}$ dish at a density of $\sim 4 \times 10^{6}$ cells. The next day cells were infected with an MOI of $\sim 50$ with the indicated recombinant adenovirus. In brief, medium was aspirated and exchanged for medium with no serum containing the virus. After $30 \mathrm{~min}$ of incubation the medium was aspirated and exchanged for fresh medium containing serum. Cells were then further incubated for the indicated time.

\section{RNA isolation and sample preparation for GeneChip ${ }^{\mathrm{TM}}$ hybridization}

Total RNA from cells either infected with AdCMV3 or AdALK1QD was isolated with the RNeasy Mini Kit (Qiagen) according to the manufacturer's instruction. Hybridization targets were prepared from $10 \mu \mathrm{g}$ of total RNA according to standard Affymetrix ${ }^{\mathrm{TM}}$ protocols (see Affymetrix $^{\mathrm{TM}}$ webpage [33]). Briefly, first strand cDNA synthesis was generated using a T7-linked oligo-dT primer, followed by second strand synthesis. An in vitro transcription reaction was performed to generate cRNA containing biotinylated UTP and CTP, which subsequently was fragmented chemically at $95^{\circ} \mathrm{C}$ for $35 \mathrm{~min}$. The fragmented, biotinylated cRNA was hybridized in MES buffer (2-[Nmorpholino]ethansulfonic acid) containing $0.5 \mathrm{mg} / \mathrm{ml}$ acetylated bovine serum albumin to the Affymetrix Human 6800 GeneChip $^{\mathrm{TM}}$ at $45^{\circ} \mathrm{C}$ for $16 \mathrm{hr}$, according to the Affymetrix protocol. Arrays were washed and stained with streptavidin-phycoerythrin (SAPE, Molecular 
Table I: Gene-specific oligonucleotides for sqRT-PCR. Primer sets were designed across exon-exon boundaries to avoid amplification of genomic DNA in the cDNA samples that might contain traces of genomic DNA. ALKI Primers were also used for qRT-PCR analyses (own assay).

\begin{tabular}{|c|c|c|c|}
\hline Gene & $\begin{array}{c}\text { Forward primer }\left(5^{\prime}-3^{\prime}\right. \\
\text { orientation) }\end{array}$ & $\begin{array}{l}\text { Reverse primer }\left(5^{\prime}-3^{\prime}\right. \\
\text { orientation) }\end{array}$ & PCR annealing Temp $\left({ }^{\circ} \mathrm{C}\right)$ \\
\hline TLS & TTGAGTCTGTGGCTGATTAC & CACTGGTTGCATTCATTCCT & 56 \\
\hline GADD/53 & GTCTAAGGCACTGAGCGTAT & TGGGGAATGACCACTCTGTT & 58 \\
\hline IL-8 & GATTGAGAGTGGACCACACT & TCGGATATTCTCTTGGCCCT & 58 \\
\hline SMAD6 & GTCTTACACTGAAACGGAGG & AGCTGATGCGGACGCTGTTG & 58 \\
\hline COL5AI & TCGATCCTAACCAAGGATGC & TGTGACGCTTCACCGAAGTC & 58 \\
\hline HEFI & GAAGAATGGGCCGGAGAGCA & GGGAAATGAAATGGGTCTCA & 56 \\
\hline TLR4 & ACAAAATCCCCGACAACCTC & ATGTAGAACCCGCAAGTCTG & 58 \\
\hline$E T-I$ & CCTGGACATCATTTGGGTCA & AGGGCTTGCCTTTCAGCTTG & 58 \\
\hline CARP & ACCGCTATAAGATGATCCGA & AATGAAGCTCTGCTCACCAG & 56 \\
\hline HPTP $\eta$ & GGGCACTTTCATTGCCATTG & CATAGCTCCСTTTTCCTGGT & 58 \\
\hline DNAJBI & ACTACTACCAGACGTTGGGC & CCGCTTGTGGGAGATTTTCG & 60 \\
\hline MGSA & GGGAATTCACCCCAAGAACA & ATCACAGTGGCTGGCATGTT & 58 \\
\hline c-myc & AGGCTATTCTGCCCATTTGG & CCACATACAGTCCTGGATGA & 58 \\
\hline$A L K I$ & GCAACCTGCAGTGTTGCATC & CGGATCTGCTCGTCCAGCAC & 60 \\
\hline GAPDH & ACCACAGTCCATGCCATCAC & TCCACCACCCTGTTGCTGTA & 60 \\
\hline
\end{tabular}

Probes). Signal amplification was performed using a biotinylated anti-streptavidin antibody (Vector Laboratories, Burlingame, CA) at $3 \mu \mathrm{g} / \mathrm{ml}$, followed by a second staining with SAPE. Normal goat IgG $(2 \mathrm{mg} / \mathrm{ml})$ was used as the blocking agent.

Measurement scans were performed using an Affymetrix GeneChip $^{\mathrm{TM}}$ confocal scanner and the MAS 4.0 average differences were computed. Scaling factors were determined for each hybridization based on a target intensity of 500 . Scaled average difference values were used in generating comparison analysis in the Affymetrix MAS 4.0 software. Briefly, in the Affymetrix MAS 4.0 comparison analysis, one array is designated as the baseline (reference sample) and the other as an experiment (test sample). The analysis compares the difference values (perfect match-mismatch) of each probe pair in the baseline array (mock infected cells) to its equivalent on the experiment array (AdALK1QD infected cells) and based on this a fold change was determined. Further explanation of the comparison analysis can be found at the Affymetrix ${ }^{\mathrm{TM}}$ webpage [33]. All GeneChip $^{\mathrm{TM}}$ raw data generated from this study can be seen online [34] (24 hour experiments: 153_22hrCMV [reference sample] versus 154_22hrALK1 [test sample], 155_22hrCMV [reference sample] versus 156_22hrALK1 [test sample], 91_22hrCMV [reference sample] versus 92_22hrALK1 [test sample]; 4 hour experiments: 66_4hrCMV [reference sample] versus 63_4hrALK1 [test sample], 89_4hrCMV [reference sample] versus 90_4hrALK1 [test sample]).

\section{RNA isolation and semi quantitative RT-PCR}

Total RNA from AdCMV3, AdLacZ or AdALK1 QD infected or non-infected cells and total RNA from TGF- $\beta$ treated or non-treated cells was isolated with the RNeasy Mini Kit (Qiagen) according to the manufacturer's instruction. For further semi quantitative RT-PCR (sqRT-PCR) or qRT-PCR $2 \mu \mathrm{g}$ of total RNA was reverse transcribed by random priming with hexamers and Oligo-dT primining $\left(\mathrm{T}_{18} \mathrm{~N}\right)$ using the Omniscript RT Kit (Qiagen) according to the manufacturer's instruction. The resulted single strand cDNA was stored in a $50 \mu$ volume at $-20^{\circ} \mathrm{C}$ until use.

For sqRT-PCR $1 \mu \mathrm{l}$ of the single strand cDNA was used in a $20 \mu \mathrm{l}$ PCR reaction mixture containing $10 \mathrm{pmol}$ of a gene specific primer pair (see Table 1), 1x PCR buffer (Invitrogen) containing $2.5 \mathrm{mM} \mathrm{MgCl}, 200 \mu \mathrm{m}$ dNTPs, 1 Unit Platinum Taq (Invitrogen). PCR conditions were as following: initial denaturing at $95^{\circ} \mathrm{C}$ for $5 \mathrm{~min}, 30$ cycles of $30 \mathrm{sec}$ denaturing at $95^{\circ} \mathrm{C}, 30 \mathrm{sec}$ primer annealing at primer specific temperature, $30 \mathrm{sec}$ elongation at $72^{\circ} \mathrm{C}$. After 30 cycles final elongation step for $5 \mathrm{~min}$. Equal amounts of PCR products were separated on $1.5 \%$ agarose gels and visualized by ethidium bromide staining.

\section{Relative quantification of gene expression using the comparative method $\left(\Delta \Delta C_{T}\right)$}

Quantitative real-time PCR (qRT-PCR) was used to measure gene expression levels in HMEC-1, HUVEC and ECRF24 cell lines under various conditions. For gene expression analysis, pre-designed gene-specific primer pairs were selected for 17 target genes and 1 endogenous control from a comprehensive catalogue of pre-designed assays named Assays-on-Demand ${ }^{\mathrm{TM}}$ (Applied Biosystems) (see Table 2). All assays were based on TaqMan hydrolysis probes labeled with $\mathrm{FAM}^{\mathrm{TM}}$ (green fluorescent fluorophore 6-carboxyfluorescein). Assays were performed on an ABI PRISM $^{\circledR} 7900$ HT Sequence Detection System (384-well 
Table 2: List of genes analysed by qRT-PCR and the corresponding pre-designed gene-specific primer pair assay (ABI Assay-on-Demand ${ }^{\mathrm{TM}}$, Applied Biosystems). Where possible RNA specific assays were selected which are depicted by_m I suffix. For CHOP_g I suffix signifies that the assay may detect DNA and for IDI the _sI suffix indicates both the primers and probe are in a single exon.

\begin{tabular}{|c|c|}
\hline GENE & ABI Assays-on-Demand ${ }^{\mathrm{TM}}$ \\
\hline ALKIIACVRLI & Hs00I63543_ml \\
\hline ALK5/TGFBRI & $\mathrm{Hs} 0061319 \_\mathrm{ml}$ \\
\hline BMP6 & $\mathrm{Hs} 00233470 \_\mathrm{ml}$ \\
\hline CARP & $\mathrm{Hs} 00173317 \_\mathrm{ml}$ \\
\hline CD/48/HPTP $\eta$ & Hs00I7456I_ml \\
\hline CHOPIDDIT3/GADD / 53 & Hs00358796_gl \\
\hline C-MYC & $\mathrm{Hs} 00 \mathrm{I} 53408 \_\mathrm{ml}$ \\
\hline Collagen Vol/COL5AI & Hs00609088_ml \\
\hline Endoglin/ENG & $\mathrm{Hs} 00164438 \_\mathrm{ml}$ \\
\hline Endothelin/ENDI & Hs00I7496I_ml \\
\hline HEFI/NEDD9 & Hs00610590_ml \\
\hline$|D|$ & Hs00704053_sl \\
\hline IL-8 & $\mathrm{Hs} 00 \mathrm{I} 74103 \_\mathrm{ml}$ \\
\hline SMAD6/MADH6 & $\mathrm{Hs} 00178579 \_\mathrm{ml}$ \\
\hline$T G F \beta R 2$ & Hs0055966I_ml \\
\hline TLR4 & $\mathrm{Hs} 00152939 \_\mathrm{ml}$ \\
\hline GAPDH & Hs99999905_ml \\
\hline
\end{tabular}

block module). For the ALK1 construct a second assay utilising SYBR Green $\mathrm{I}^{\circledast}$ was used in conjunction with the primer pair designed for the sqRT-PCR detection of ectopic $A L K 1$ expression along with a SYBR Green $I^{\oplus}$ assay designed to GAPDH. The SYBR Green $\mathrm{I}^{\circledR}$ assays were performed on an ABI PRISM ${ }^{\circledast} 7700$ Sequence Detection System (96-well block module).

Once RNA was extracted and reverse transcribed the cDNA was diluted 1 in 50 and assayed in $20 \mu \mathrm{l}$ reaction volumes. For the assays on demand each reaction comprised of $5 \mu \mathrm{l}$ cDNA, $10 \mu \mathrm{l}$ 2x qPCR Master Mix with uracil-N-glycosy- lase (Eurogentec), $1 \mu \mathrm{l}$ 20x Primer/Probe Assay mix (Applied Biosystems), the SYBR Green $\mathrm{I}^{\circledast}$ assays comprised of $5 \mu \mathrm{l} \mathrm{cDNA}, 10 \mu \mathrm{l} 2 \mathrm{x}$ SYBR Green $\mathrm{I}^{\circledast}$ Master Mix (Applied Biosystems) and $10 \mathrm{pmol}$ each primer. Samples were then amplified on an ABI PRISM ${ }^{\otimes} 7900$ HT or 7700 using the following conditions; $50^{\circ} \mathrm{C}$ for $2 \mathrm{~min}, 95^{\circ} \mathrm{C}$ for $10 \mathrm{~min}$ followed by 40 cycles of $95^{\circ} \mathrm{C}$ for $15 \mathrm{sec}$ and $60^{\circ} \mathrm{C}$ for 1 min. Samples were assayed in triplicate for each gene, and the mean expression was used during subsequent analysis. Analyses were done with the Applied Biosystems SDS 7900 or 7700 system software, version 2.2 or 1.2, respectively. Relative expression was calculated using the comparative $\Delta \Delta \mathrm{C}_{\mathrm{T}}$ method (Bulletin \#2, ABI, Foster City, USA). In brief, the comparative method of analysis compares the amounts of target gene expression relative to an endogenous control, such as GAPDH, within a sample to normalise the expression. Within a group of samples, one appropriate sample is elected as a reference sample. Each sample is then compared to the nominated reference sample to give the relative expression of the target gene compared to this reference sample (see Table 3 ).

\section{Results}

\section{Gene expression in HMEC-I cells 24 hours post AdALKIQD} infection

In order to evaluate gene expression specifically induced by ALK1, and not by ALK5, HMEC- 1 cells, a human microvascular endothelial cell line [30], were infected with the recombinant adenovirus AdALK1QD expressing the constitutively active form of ALK1. HMEC-1 cells infected with the empty adenovirus vector AdCMV3 served as reference. 24 hours after infection total RNA was isolated and used for hybridization on an Affymetrix HuGeneFL GeneChip ${ }^{\mathrm{TM}}$ representing over 5,600 genes. This experiment was produced in triplicate, and only genes that showed at least a two-fold expression change were considered for further evaluation. 11 genes displayed more than a 2 -fold increase in all three experiments. 22

Table 3: The selection of reference samples used for each of the comparative analyses for relative gene expression calculation based on qRT-PCR.

HMEC-I + AdCMV3 24 hr; Experiment I HMEC-I + AdCMV3 24 hr; Experiment 2 HMEC-I + AdCMV3 24 hr; Experiment 3 HMEC-I + AdCMV3 4 hr; Experiment I HMEC-I + AdCMV3 4 hr; Experiment 2 HUVEC, no virus

ECRF24 cells no virus

HMEC-I no TGF- $\beta$ I, 16 hr incubation

HMEC-I no TGF- $\beta$ I, 24 hr incubation
HMEC-I + AdALKIQD 24 hr; Experiment I HMEC-I + AdALKIQD 24 hr; Experiment 2 HMEC-I + AdALKIQD 24 hr; Experiment 3

HMEC-I + AdALKIQD 4 hr; Experiment I

HMEC-I + AdALKIQD 4 hr; Experiment 2

HUVEC + AdCMV3

HUVEC + AdALKIQD

ECRF24 + AdLacZ

ECRF24 + AdALKIQD

HMEC-I, $0.5 \mathrm{ng} / \mathrm{ml}$ TGF- $\beta \mathrm{I}, 16 \mathrm{hr}$ incubation HMEC-I, $4.0 \mathrm{ng} / \mathrm{mlTGF}-\beta \mathrm{I}, 16 \mathrm{hr}$ incubation HMEC-I, $0.5 \mathrm{ng} / \mathrm{mlTGF}-\beta \mathrm{I}, 24 \mathrm{hr}$ incubation HMEC-I, $4.0 \mathrm{ng} / \mathrm{ml}$ TGF- $\beta$ I, $24 \mathrm{hr}$ incubation 
genes showed increased expression in two out of three experiments. 15 genes were up-regulated by 2-fold or more in the first two replicate experiments, and 4 genes were up-regulated by $\geq 2$-fold in replicate experiments 1 and 3 . Three genes were up-regulated by $\geq 2$-fold in replicate experiments 2 and 3 . We tried to identify genes that were down-regulated by ALK1 signalling but there was no consistent expression pattern of down-regulated genes among the three experiments. Table 4 lists all the genes up-regulated by $\geq 2$-fold in at least two out of three experiments. Genes are arranged according to groupings based on current known biological functions.

Highest induction in all three experiments was seen for a probe with no assigned GenBank number named by Affymetrix as oncogene TLS/CHOP suggesting that this probe represents a fusion gene. Other names for $\mathrm{CHOP}$ are DDIT3 or GADD153. sqRT-PCR revealed that GADD153 was the gene in question and not TLS (data not shown). Therefore, all further analyses were done for GADD153.

To validate the gene array results we performed qRT-PCR and sqRT-PCR for a subset of genes using the same RNA that was used for the GeneChip ${ }^{\mathrm{TM}}$ hybridizations. qRT-PCR was done for genes up-regulated in all three experiments as well as for BMPG (increased expression only seen in experiment 1 and 2), ALK5, T $\beta R I I$, endoglin and $c-m y c$. Our gene array data did not suggest an influence of ALK1 on endoglin or $c$ - $m y c$ expression but previous microarray data had shown that ALK1 signalling up-regulates endoglin in primary HUVECs [35] and down-regulates $c-m y c$ in primary dermal microvascular endothelial cells [36]. Because, TGF- $\beta 1$ is known to induce its own receptors [37], ALK5 and TRRII expression was also examined by qRT-PCR. Also tested by sqRT-PCR was the chemokine $M G S A / G R O \alpha$ that had shown increased expression only in two out of three experiments. qRT-PCR revealed that endoglin and BMPG expression was increased by more than 2-fold in all three experiments (Table 4). Up-regulated expression in all three experiments was also seen for $M G S A / G R O \alpha$ (data not shown). Expression values for $A L K 5, T \beta R I I$ and $c-m \psi c$ were unchanged across methods.

The ectopic expression of ALK1 due to AdALK1 QD infection was not detected by GeneChip ${ }^{\mathrm{TM}}$ hybridization in the first two experiments. The ABI qRT-PCR assay for ALK1 is designed against exon 1 /exon 2 but the coding sequence for ALK1 starts in exon 2. Thus, the ABI assay Hs00163543_m1 will not detect ALK1 expression from the AdALK1QD construct, since this one contains only the ALK1 coding sequence. qRT-PCR assays with primers located in exon 7/exon 8 (own assay) revealed ALK1 expression in all three experiments with a mean expres- sion level of RQ = $5079.92(8659.09 / 2475.21 / 4105.47)$ confirming high levels of ectopic ALK1QD expression.

\section{Gene expression in HMEC-I cells 4 hours post AdALKIQD infection}

The previous experiments assayed ALK1 induced gene expression after 24 hours. In order to identify ALK1 early response genes, HMEC-1 cells were infected with AdALK1 $1 \mathrm{QD}$ and RNA was isolated 4 hours post-infection. AdCMV3 infected HMEC-1 cells served as reference. The isolated RNA of two independent experiments was used for Affymetrix HuGeneFL GeneChip ${ }^{\text {TM }}$ analysis as well as for qRT-PCR analysis for a selected set of genes (genes upregulated after 24 hours in all three experiments). By qRTPCR analysis AdALK1QD infected cells showed high ectopic ALK1 expression (own qRT-PCR assay) with a mean level of $R Q=157.795$. Most of the genes identified to be up-regulated after 24 hours showed no significant changes over controls after 4 hours except for $I L-8$ (RQ = $0.595)$ and GADD153 (RQ $=0.69)$, which were consistently down-regulated. This time dependent response suggests that there is an early response component to ALK1 signalling for $I L-8$ and GADD153 but their subsequent upregulation after 24 hours might be an indirect effect of prolonged ALK1 signalling.

Affymetrix HuGeneFL GeneChip ${ }^{\mathrm{TM}}$ analysis identified 13 genes to be up-regulated by more than 1.5 -fold and 2 genes were down-regulated by more than 1.5 -fold in both experiments (see Table 5). For the purpose of identifying early response genes the threshold for fold changes in gene expression was this time set to 1.5. ALK1 expression levels were measured to be 53.85 (experiment 1: 58.5; experiment 2: 49.2). Thus, both the GeneChip ${ }^{\mathrm{TM}}$ hybridization and qRT-PCR methods demonstrated high ectopic ALK1 QD expression levels already after 4 hours of viral infection. Of the genes up-regulated after 24 hours only two genes, SMAD7 and KPNA3, showed increased expression after 4 hours suggesting these genes were directly regulated by ALK1 signalling. The identified early response genes can be roughly divided into four functional groups: transcription factors (REST, TEAD4 and NFIB), vesicle transport/protein sorting (RAB6A, TM9SF2 and PICALM), targeted protein degradation (CUL4A, COPS6), and signalling (KPNA3, SMAD7, GNA13, NF2, PLCL1). LOC400986 and BCAT1 are classified as miscellanous due to the lack of clear functional data to our knowledge.

\section{Gene expression in AdALKIQD infected ECRF24 cells and primary HUVECs}

To determine if different endothelial cell types react differently to ALK1 signalling we compared AdALK1QD-infected ECRF24 and primary HUVEC cells versus HMEC-1 cells. We used cells infected with AdCMV3 or the same vector containing an irrelevant gene, LacZ (AdLacZ), as controls 
Table 4: Constitutively active ALKI regulated gene expression in HMEC-I cells after 24 hours. Gene expression profiling by Affymetrix GeneChip ${ }^{T M}$ and qRT-PCR analysis for HMEC-I cells (human microvascular endothelial cell line) infected with empty adenovirus (AdCMV3) or AdALKIQD. Listed are genes up-regulated in at least two out of three independent experiments. Cells were infected with an MOI of $\sim 50$. Gene expression was assesed after 24 hours. Gene expression profile of AdCMV3 infected cells served as reference. GeneChip ${ }^{\mathrm{TM}}$ raw data was analysed using Affymetrix MAS 4.0 comparison analysis. Listed are the mean results. Information about gene function was taken from NCBI Entrez Gene data base if not otherwise indicated. $q R T$ TPCR based relative gene expression was calculated using the comparative $\Delta \triangle C_{T}$ method. RQ represents the relative expression level (fold change) compared to the reference sample. $\mathbf{R} \mathbf{Q}_{\operatorname{Max} / \mathrm{Min}}$ are the relative maximum/minimum expression levels of the mean expression level $\mathbf{R Q}$.

Gene/Gene aliases [GenBank number]

\begin{tabular}{|c|c|c|c|c|}
\hline Transcription factors & Gene description & $\begin{array}{l}\text { GeneChip }{ }^{T M} \text { fold } \\
\text { change (StdDev) }\end{array}$ & $\begin{array}{l}\text { qRT-PCR RQ } \\
\left(\mathrm{RQ}_{\mathrm{Max} / \mathrm{Min}}\right)\end{array}$ & $\begin{array}{l}\text { TGF- } \beta \text { regulated } \\
\text { (Ref.) }\end{array}$ \\
\hline 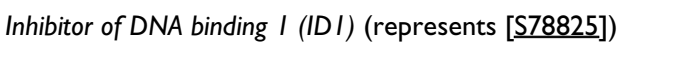 & $\begin{array}{l}\text { role in cell growth, senescence, and differentiation, } \\
\text { involved in angiogenesis }\end{array}$ & $2.86(0.7 I)$ & $6.56(9.83 / 4.42)$ & {$[6,70]$} \\
\hline Inhibitor of DNA binding IB (IDIB) [S78825] & $\begin{array}{l}\text { role in cell growth, senescence, and differentiation, } \\
\text { involved in angiogenesis }\end{array}$ & $14 *$ & nt & - \\
\hline Inhibitor of DNA binding 2 (ID2) [M97796] & role in cell growth and differentiation & $17.6^{*}$ & nt & {$[70]$} \\
\hline Inhibitor of DNA binding 2B (ID2B) [M96843] & function unknown & $8.15^{*}$ & nt & - \\
\hline Ankyrin repeat domain I (ANKRDI)/CARP [ & $\begin{array}{l}\text { endothelial and smooth muscle cell expression, angiogenic } \\
\text { activity [7I] }\end{array}$ & $4.46(2.80)$ & $4.29(|3.70 / 2.4|)$ & {$[41]$} \\
\hline High mobility group AT-hook 2 (HMGA2) [ $\underline{\mathrm{U} 28749}$ ] & $\begin{array}{l}\text { HMG proteins are essential components of the } \\
\text { enhancesome, may act as a transcriptional regulating factor }\end{array}$ & $6^{*}$ & nt & - \\
\hline \multicolumn{5}{|l|}{ Signalling molecules } \\
\hline Interleukin 8 (IL-8) [M28|30] & inflammatory response, angiogenic factor & $18.26(10.83)$ & $\begin{array}{l}1056.07(1686.10 / \\
666.22)\end{array}$ & {$[72-74]$} \\
\hline Endothelin (EDNI)/ET-I [105008] & vaso constrictor, involved in angiogenesis & $3.36(0.30)$ & $3.87(5.16 / 2.97)$ & [75] \\
\hline $\begin{array}{l}\text { Chemokine (C-X-C motif) ligand I (CXCLI)/GRO } \alpha \text { I /MGSA } \\
{[\underline{X 54489]}}\end{array}$ & immune response, tumor progression, angiogenic activity & $8.2^{*}$ & nt & [70] \\
\hline Bone morphogenetic protein 6 (BMP6) [M603I5] & $\begin{array}{l}\text { induced by proinflammatory cytokines, involved in bone } \\
\text { and cartilage development }\end{array}$ & $3.8^{*}$ & $4.26(5.60 / 3.30)$ & {$[70,76]$} \\
\hline 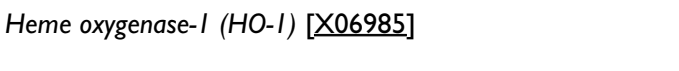 & $\begin{array}{l}\text { heme catabolism, beneficial in cerebrovascular events, } \\
\text { vasodilator }\end{array}$ & $3.8^{*}$ & nt & [77] \\
\hline Jagged I (JAGI) [U73936] & ligand for notch I, involved in angiogenesis & $3.9 *$ & $\mathrm{nt}$ & [78] \\
\hline Parathyroid hormone-like hormone (PTHLH) [M2435I] & involved in cell proliferation, apoptosis, cancer & $2.35^{*}$ & $\mathrm{nt}$ & {$[79,80]$} \\
\hline \multicolumn{5}{|l|}{ Signal transduction/regulation } \\
\hline SMAD6 [U599|4] & inhibitor of TGF- $\beta$ family member signaling 2 & $14.2(9.41)$ & $14.56(|8.63 /| 1.63)$ & {$[81]$} \\
\hline Toll-like receptor 4 (TLR4) [ㅂ93091] & LPS innate immune response & $4.33(1.19)$ & $3.98(5.51 / 2.92)$ & - \\
\hline $\begin{array}{l}\text { Protein tyrosine phosphatase, receptor type, J (PTPRJ)/CD / 48/ } \\
\text { HPTP } \eta[\mathrm{D} 37781]\end{array}$ & involved in cell proliferation, differentiation, cell motility & $3.56(1.58)$ & $2.08(3.01 / 1.47)$ & - \\
\hline SMAD7 [ & inhibitor of TGF- $\beta$ family member signaling 2 & $7.2^{*}$ & $\mathrm{nt}$ & {$[81]$} \\
\hline Ras homolog gene family, member B (RHOB) [M|2|74] & role in endosomal trafficking [82] & $3.25^{*}$ & $\mathrm{nt}$ & {$[70]$} \\
\hline $\begin{array}{l}\text { Mitogen-activated protein kinase kinase kinase } 5 \text { (MAP3K5) } \\
\text { [U67156] }\end{array}$ & activates c-Jun $\mathrm{N}$-terminal kinase (JNK) & $3.2^{*}$ & $\mathrm{nt}$ & - \\
\hline Endoglin (ENG)/CDI05 (J0548I) & TGF- $\beta$ I, $-\beta 3$ accessory receptor and signaling modulator & nd & $2.36(3.08 / 1.84)$ & {$[83]$} \\
\hline Extracellular matrix & & & & \\
\hline
\end{tabular}


Table 4: Constitutively active ALKI regulated gene expression in HMEC-I cells after 24 hours. Gene expression profiling by Affymetrix GeneChip ${ }^{T M}$ and qRT-PCR analysis for HMEC-I cells (human microvascular endothelial cell line) infected with empty adenovirus (AdCMV3) or AdALKIQD. Listed are genes up-regulated in at least two out of three independent experiments. Cells were infected with an MOI of $\sim 50$. Gene expression was assesed after 24 hours. Gene expression profile of AdCMV3 infected cells served as reference. GeneChip ${ }^{T M}$ raw data was analysed using Affymetrix MAS 4.0 comparison analysis. Listed are the mean results. Information about gene function was taken from NCBI Entrez Gene data base if not otherwise indicated. $\mathrm{QRT}$-PCR based relative gene expression was calculated using the comparative $\Delta \triangle C_{\mathrm{T}}$ method. RQ represents the relative expression level (fold change) compared to the reference sample. $R \mathbf{Q}_{\operatorname{Max} / \mathrm{Min}}$ are the relative maximum/minimum expression levels of the mean expression level $\mathbf{R Q}$.

\begin{tabular}{|c|c|c|c|c|}
\hline Collagen $5 \alpha$ l (COL5AI) [D90279] & controls the initiation of collagen fibril assembly [62] & $7.13(4.27)$ & $2.28(2.93 / I .8 I)$ & {$[59,60]$} \\
\hline $\begin{array}{l}\text { Serine (or cysteine) proteinase inhibitor I (SERPINHI)/HSP47 } \\
\text { [D83I74] }\end{array}$ & assists maturation of the ECM protein type I collagen & $2^{*}$ & nt & {$[58]$} \\
\hline
\end{tabular}
[D83174]

Stress response

DNA-damage-inducible transcript 3 (DDIT3)/ GADD/53 [S40706]

Dnaj (Hsp40) homolog, subfamily B, member I (DNAJBI)

D85429]

Homocysteine inducible, endoplasmic reticulum stress-induch

ubiquitin-like domain member I (HERPUDI) [DI4695]

Cell adhesion and cytoskelet

Neural precursor cell expressed, developmentally downregulated 9 (NEDD9)/ HEFI [L4382I]

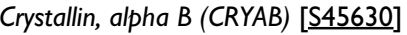

Tropomyosin I (alpha) (TPMI), splice variant 2 Poliovirus receptor (PVR)/CD I 55 [M24407]

Solute carrier family 3, member 2 (SLC3A2)/CD98 [M21904]

Miscellanous transcription factor, associated with cell stress and apoptosis

linked to the $26 \mathrm{~S}$ proteasome, up-regulated in bipolar disorder

linked to the $26 \mathrm{~S}$ proteasome, up-regulated by Wnt-I

\section{$19.5(2.60)$}

$3.03(1.00)$

$4 . I^{*}$
$4.55(6.42 / 3.27)$

nt

nt actin filament bundle formation, cell adhesion, cytoskeleton organization and biogenesis, integrin mediated signalling pathway, regulation of cell cycle, regulation of cell growth, signal transduction

member of the small heat shock protein (HSP20) family, assists assembly of desmin filaments [85]

associated with the actin filaments

also involved in the regulation of cell adhesion and cell motility [89]

activator of dibasic and neutral amino acid transport, mediates integrin signaling [90]
$5.8(0.95)$

$3.93(5.74 / 2.73)$

$11.1 *$

nt

$2.3^{*}$

$2.35^{*}$

$2.5^{*}$

nt

nt

nt

$[85,86]$

$[87,88]$

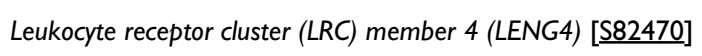
Karyopherin alpha 3 (KPNA3) [Y12394]

Ankyrin repeat domain I5 (ANKRDI5) [D79994]

Over-expressed in bladder and breast carcinoma nuclear transport protein $91 \mathrm{la}$

plays a role in cell growth

catalyzes the first oxygenation step in sterol biosynthesis

$2.1^{*}$
$2.75^{*}$
$2.3^{*}$
$2.45^{*}$

$\mathrm{nt}$
$\mathrm{nt}$
$\mathrm{nt}$
$\mathrm{nt}$

The measurements of fold-change with a symbol in front of them are an approximation because the average difference in the reference samples were not above background; ${ }^{*}$ mean of two experiments; nd, not detected; $\mathrm{nt}$, not tested. 
Table 5: Constitutively active ALKI regulated gene expression in HMEC-I cells after 4 hours. Gene expression profiling by Affymetrix GeneChip $^{\mathrm{TM}}$ analysis for HMEC-I cells (human microvascular endothelial cell line) infected with empty adenovirus (AdCMV3) or AdALKIQD. Cells were infected with an MOI of $\sim 50$. Gene expression was assessed after 4 hours. Gene expression profile of AdCMV3 infected cells served as reference. GeneChip ${ }^{T M}$ raw data was analysed using Affymetrix MAS 4.0 comparison analysis. Listed are the mean results of two independent experiments. Information about gene function was taken from NCBI Entrez Gene data base if not otherwise indicated.

\begin{tabular}{|c|c|c|c|}
\hline Gene/Gene aliases [GenBank number] & Gene description & GeneChip $^{\mathrm{TM}}$ fold change & TGF- $\beta$ regulated \\
\hline $\begin{array}{l}\text { RAS oncogene family member } 6 A(R A B 6 A) \\
{[M 28212]}\end{array}$ & $\begin{array}{l}\text { regulates a retrograde transport route } \\
\text { connecting endosomes and the endoplasmic } \\
\text { reticulum (ER) via the Golgi apparatus }\end{array}$ & $4.35(3.6 / 5.1)$ & - \\
\hline 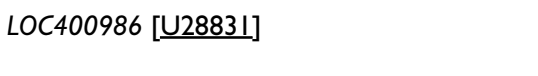 & $\begin{array}{l}\text { protein immuno-reactive with anti-PTH } \\
\text { polyclonal antibodies }\end{array}$ & $4.1(3.1 / 5.1)$ & - \\
\hline $\begin{array}{l}\text { REI-silencing transcription factor (REST) } \\
{[\underline{\mathrm{U} 223 \mid 4]}}\end{array}$ & $\begin{array}{l}\text { may function as a master negative-regulator of } \\
\text { neurogenesis [92]; may play a role in vascular } \\
\text { smooth muscle cells and human vascular } \\
\text { disease }[92,93]\end{array}$ & $3.25(1.8 / 4.7)$ & - \\
\hline Karyopherin alpha 3 (KPNA3) [YI2394] & nuclear transport protein $[91]$ & $2.9(3.1 / 2.7)$ & - \\
\hline $\begin{array}{l}\text { Guanine nucleotide binding protein (G protein), } \\
\text { alpha I } 3 \text { (GNA I3) [L22075] }\end{array}$ & $\begin{array}{l}\text { plays a critical role in endothelial cells during } \\
\text { vascular development, knock outs are } \\
\text { embryonical lethal [54] }\end{array}$ & $2.65(1.8 / 3.5)$ & - \\
\hline $\begin{array}{l}\text { Transmembrane } 9 \text { superfamily member } 2 \\
\text { (TM9SF2) [U81006] }\end{array}$ & $\begin{array}{l}\text { may function as an endosome ion channel or } \\
\text { small molecule transporter }\end{array}$ & $2.45(3.3 / 1.6)$ & - \\
\hline SMAD7 [AFOI0193] & inhibitor of TGF- $\beta$ family member signaling & $2.35(1.9 / 2.8)$ & {$[81]$} \\
\hline Cullin 4A (CUL4A) U58090] & $\begin{array}{l}\text { belongs to the cullin family of E3 ubiquitin } \\
\text { ligases }\end{array}$ & $2.3(2.0 / 2.6)$ & - \\
\hline $\begin{array}{l}\text { Branched-chain aminotransferase I (BCATI) } \\
\text { [U2|55I] }\end{array}$ & $\begin{array}{l}\text { cytosolic and mitochondrial function, direct } \\
\text { genetic target for Myc regulation }\end{array}$ & $2.05(1.8 / 2.3)$ & - \\
\hline $\begin{array}{l}\text { Phosphatidylinositol-binding clathrin assembly } \\
\text { protein (PICALM) [U45976] }\end{array}$ & involved in clathrin-mediated endocytosis & $1.85(2.1 / 1.6)$ & - \\
\hline $\begin{array}{l}\text { TEA domain family member } 4 \text { (TEAD4) } \\
\text { [U63824]) }\end{array}$ & $\begin{array}{l}\text { member of the transcriptional enhancer factor } \\
\text { (TEF) family, directs muscle-specific gene } \\
\text { expression, induces VEGF expression in } \\
\text { endothelial cells [55] }\end{array}$ & $1.8(1.8 / 1.8)$ & - \\
\hline Nuclear factor I/B (NFIB) [U 85|93] & $\begin{array}{l}\text { essential for both lung maturation and brain } \\
\text { development [94] }\end{array}$ & $\mathrm{I} .75(\mathrm{I} .8 / \mathrm{I} .7)$ & - \\
\hline 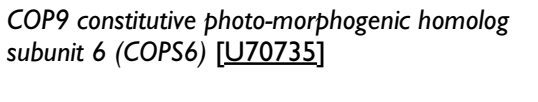 & $\begin{array}{l}\text { subunit of COP9 signalosome, involved in the } \\
\text { regulation of Cullin-containing ubiquitin E3 } \\
\text { ligases [95] }\end{array}$ & $1.7(1.9 / 1.5)$ & - \\
\hline Neurofibromin 2 (NF2) & $\begin{array}{l}\text { similar to members of the ERM (ezrin, radixin, } \\
\text { moesin) family, links cytoskeletal components } \\
\text { with proteins in the cell membrane }\end{array}$ & $-2.8(1.6 / 4.0)$ & - \\
\hline Phospholipase C-like I (PLCLI) [D42108] & $\begin{array}{l}\text { involved in inositol phospholipid-based } \\
\text { intracellular signaling cascade }\end{array}$ & $-2.4(2.3 / 2.5)$ & - \\
\hline
\end{tabular}

for bystander effects of viral infection. Non-infected ECRF24 cells and HUVECs served as reference.

Infection with recombinant control adenoviruses had no effect on $I L-8$ or GADD153, whereas it appears as if viral infection leads to decreased HEF1, CARP, ALK5 and ALK1 expression in HUVECs as well as ECRF24 cells. Constitutively active ALK1 signalling induced different gene expression responses in ECRF24 cells, HUVECs and HMEC-1 cells (see Table 6). ALK1QD up-regulated GADD153, IL-8, SMAD6, and ID1 in all three endothelial cell types. Increased expression of TLR4, endothelin, CARP and endoglin was only seen for primary HUVECs and HMEC-1 cells but not for ECRF24. In contrast, increased HEF1 expression by more than 3-fold was observed for ECRF24 and HMEC-1 cells but not for primary HUVECs.
Furthermore, constitutively active ALK1 signalling decreased T $\beta R I I$ expression in ECRF24, but not HUVECs or HMEC-1 cells, and ALK5 expression was completely blocked in primary HUVECs, but unchanged in ECRF24 and HMEC-1 cells. These results suggest that within the endothelial cell lineage there is a notable cell type difference in ALK1-induced gene expression.

\section{TGF- $\beta$ I regulated gene expression of $A L K I$ response genes in HMEC-I cells}

Thus far, ALK1 response genes were induced by a constitutively active ALK1 that does not require ligand binding for signal initiation. Since ALK1 is a TGF- $\beta 1$ receptor, we wanted to know if these genes become regulated by TGF$\beta 1$, and in particular whether there are any differences between high or low concentrations of TGF- $\beta 1$, which 
Table 6: Constitutively active ALKI regulated gene expression in primary HUVECs and the HUVEC cell line ECRF24. ECRF24 cells were infected with an $\mathrm{MOI}$ of $\sim 50$ with the recombinant adenovirus AdLacZ, containing the LacZ gene, or AdALK IQD, respectively. Primary HUVECs were infected with an MOI of $\sim 50$ with the empty AdCMV3 adenovirus or AdALK IQD, respectively. Gene expression was assessed after 24 hours by qRT-PCR. Non-infected cells served as reference. qRT-PCR based relative gene expression was calculated using the comparative $\Delta \Delta C_{\mathrm{T}}$ method. $\mathrm{RQ}$ represents the relative expression level (fold change) compared to the reference sample. $R Q_{\text {Max/Min }}$ are the relative maximum/minimum expression levels of the mean expression level $R Q$. The right column titled HMEC-I shows in comparison the mean RQ level of three independent experiments with HMEC-I cells infected with AdALKIQD (see Table 4). Genes with RQ values in bold are considered to be up-regulated.

\begin{tabular}{|c|c|c|c|c|c|}
\hline \multirow[b]{2}{*}{ Gene [GenBank number] } & \multicolumn{2}{|c|}{ ECRF24 } & \multicolumn{2}{|c|}{ primary HUVECs } & \multirow{2}{*}{$\begin{array}{c}\text { HMEC-I } \\
\text { AdALK IQDRQ }\end{array}$} \\
\hline & $\begin{array}{c}\text { AdLacZ RQ } \\
\left(R_{\text {Max/Min }}\right)\end{array}$ & $\begin{array}{l}\text { AdALKIQDRQ } \\
\left(\mathrm{RQ}_{\operatorname{Max} / \operatorname{Min}}\right)\end{array}$ & $\begin{array}{c}\text { AdCMV3 RQ } \\
\left(R_{\text {Max/Min }}\right)\end{array}$ & $\begin{array}{l}\text { AdALKIQDRQ } \\
\left(\mathrm{RQ}_{\text {Max/Min }}\right)\end{array}$ & \\
\hline GADD / 53 [S40706] & $0.95(1.07 / 0.85)$ & $4.21(5.27 / 3.37)$ & $1.17(1.27 / 1.07)$ & $7.53(12.05 / 4.70)$ & 4.55 \\
\hline IL-8 [M28|30] & $1.13(1.01 / 1.27)$ & I I.55 (13.60/9.8I) & $1.52(2.55 / 0.90)$ & $4.37(5.57 / 3.44)$ & 1056.07 \\
\hline SMAD6 [ㄴ599|4] & $0.82(0.90 / 0.75)$ & $5.65(6.59 / 4.84)$ & $1.30(1.44 / 1.17)$ & $38.89(44.26 / 34.18)$ & I4.56 \\
\hline COL5AI [D90279] & $1.04(1.15 / 0.94)$ & $1.68(1.94 / 1.45)$ & $1.00(1.10 / 0.92)$ & $3.47(4.06 / 2.96)$ & 2.28 \\
\hline$H E F I$ [Lئ4382I] & $0.89(0.98 / 0.81)$ & $3.88(4.55 / 3.31)$ & $0.61(0.66 / 0.56)$ & $1.18(1.75 / 0.80)$ & 3.93 \\
\hline TLR4 [U93091] & $0.95(1.06 / 0.85)$ & $1.59(1.82 / 1.39)$ & $1.02(1.12 / 0.93)$ & $4.77(5.70 / 3.99)$ & 3.98 \\
\hline$E T-I[105008]$ & $0.64(0.70 / 0.59)$ & $0.73(0.86 / 0.61)$ & $1.07(1.16 / 0.99)$ & $2.21(2.62 / 1.87)$ & 3.87 \\
\hline CARP $[\underline{X 83703}]$ & $0.61(0.74 / 0.50)$ & $0.79(1.08 / 0.58)$ & $0.83(1.00 / 0.69)$ & $1.94(2.82 / 1.33)$ & 4.29 \\
\hline $\mathrm{HPTP} \eta[\mathrm{D} 37781]$ & $1.69(1.90 / 1.51)$ & $1.54(2.75 / 0.86)$ & \# & \# & 2.08 \\
\hline IDI [ $\underline{\mathrm{S78825}}]$ & $0.70(0.78 / 0.63)$ & $2.06(2.45 / 1.73)$ & $1.40(1.79 / 1.09)$ & $4.04(6.63 / 2.46)$ & 6.56 \\
\hline BMP6 [M603।5] & $0.64(0.70 / 0.57)$ & $0.72(0.82 / 0.63)$ & $0.91(1.15 / 0.73)$ & $1.61(2.04 / 1.27)$ & 4.26 \\
\hline$A L K 5$ [니1695] & $0.68(0.78 / 0.59)$ & $0.95(1.25 / 0.7 I)$ & $0.4 I(0.44 / 0.38)$ & nd & 1.36 \\
\hline$T \beta R I I[\mathrm{M} 85079]$ & $1.18(1.31 / 1.06)$ & $0.77(0.91 / 0.65)$ & $0.96(1.04 / 0.89)$ & $1.38(1.65 / 1.16)$ & 1.26 \\
\hline Endoglin [10548I] & $0.83(0.93 / 0.74)$ & $1.19(1.60 / 0.89)$ & $1.02(1.10 / 0.95)$ & $3.05(4.07 / 2.29)$ & 2.36 \\
\hline 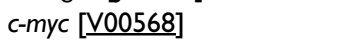 & $0.85(1.03 / 0.70)$ & $0.78(0.90 / 0.67)$ & $1.00(1.17 / 0.86)$ & $1.05(1.64 / 0.67)$ & 1.45 \\
\hline ALKI [LI I7075] (ABI assay) & $0.95(1.09 / 0.83)$ & $0.93(1.11 / 0.77)$ & $0.86(0.93 / 0.79)$ & $1.44(2.28 / 0.91)$ & 1.40 \\
\hline ALKI [Lㅣ 7075] (own assay) & 0.50 & $597.72 *$ & 0.55 & $197.18^{*}$ & $5079.92 *$ \\
\hline
\end{tabular}

nd, not detected after 40 cycles; \#, not detected after 40 cycles and not detected in the reference sample; *, ectopic expression

reportedly activate either the ALK5 or the ALK1 pathway $[6,29]$.

Approximately $80 \%$ confluent cells were incubated with $0.5 \mathrm{ng} / \mathrm{ml}$ or $4 \mathrm{ng} / \mathrm{ml}$ TGF- $\beta 1$, respectively, for 16 hours and 24 hours, respectively, which would reflect the time intervall at which $\mathrm{ALK} 1{ }^{\mathrm{QD}}$ regulated gene expression was assesed before. Expression levels of ALK1 response genes were investigated by qRT-PCR and levels in TGF- $\beta 1$ treated cells were compared to non-TGF- $\beta 1$ treated cells. The expression profiles of TGF- $\beta 1$ treated cells after 16 hours or 24 hours were almost identical regardless of TGF$\beta 1$ concentration (Table 7, for simplification only the 24 hr expression levels are listed). Gene expression levels with $\mathrm{RQ}$ values at or above 2 were considered to be increased and RQ levels below 0.90 were considered to be decreased. Four genes, COL5A1, HEF1, endothelin and $B M P 6$ were up-regulated at both concentrations and time points; surprisingly $c-m y c$ expression was also increased being maximally up-regulated after 16 hours [RQ 1.66 (0.5 ng TGF- $\beta 1 / \mathrm{ml})$ and RQ 1.99 (4 ng TGF- $\beta 1 / \mathrm{ml})]$. Three genes, GADD153, IL-8 and SMAD6 previously shown to be up-regulated by constitutively active ALK1 showed suppression at all conditions. TLR4, CARP and ID1 expression after 24 hours was decreased after treat- ment with low TGF- $\beta 1$ concentrations but unchanged with high TGF- $\beta 1$ concentrations. In summary, most of the studied genes showed a distinct expression profile in response to constitutively active ALK1 and TGF- $\beta 1$ and only COL5A1, HEF1, endothelin and BMPG expression was concordant.

\section{TGF- $\beta$ I dose-dependent regulation of ALKI response genes in primary HUVECs}

Although it was reported that TGF- $\beta 1$ regulates gene expression differently in a dose dependent manner our analyses for the ALK1 response genes did not reveal such a regulatory mechanism for HMEC-1 cells. However, these experiments were performed with a cell line and immortalized cells may act differently than primary cells as used by Goumans and colleagues [6]. Thus, we used primary HUVECs to investigate what effect different TGF- $\beta 1$ concentrations might have on the expression of ALK1 response genes. Approximately $80 \%$ confluent primary HUVECs were treated with different concentrations of TGF- $\beta 1(0.25 \mathrm{ng} / \mathrm{ml}, 0.5 \mathrm{ng} / \mathrm{ml}, 1 \mathrm{ng} / \mathrm{ml}, 4 \mathrm{ng} / \mathrm{ml})$ for 16 hours. Gene expression levels of a selected set of genes were compared to non-TGF- $\beta 1$ treated cells by sqRT-PCR. 
Table 7: TGF- $\beta$ I regulated gene expression of ALKI response genes in HMEC-I cells. HMEC-I cells (human microvascular endothelial cell line) were incubated with the indicated amounts of TGF- $\beta$ I. Gene expression after 24 hours was assesed by qRT-PCR. Gene expression profile of non-TGF- $\beta$ I treated cells served as reference. qRT-PCR based relative gene expression was calculated using the comparative $\Delta \Delta \mathbf{C}_{\mathrm{T}}$ method. $\mathbf{R Q}$ represents the relative expression level (fold change) compared to the reference sample. $\mathbf{R Q} \mathbf{Q}_{\mathrm{Max} / \mathrm{Min}}$ are the relative maximum/minimum expression levels of the mean expression level $R Q$. The right column shows in comparison the average RQ level of three independent experiments with HMEC-I cells infected with AdALKI QD (see Table 4). Genes with RQ values in bold are considered to be up-regulated and RQ values in italic are considered to be down-regulated.

\begin{tabular}{|c|c|c|c|}
\hline & \multicolumn{3}{|c|}{ HMEC-I } \\
\hline & $0.5 \mathrm{ng}$ TGF- $\beta \mathrm{I} / \mathrm{ml}$ & $4 \mathrm{ng}$ TGF- $\beta \mathrm{I} / \mathrm{ml}$ & AdALKIQD \\
\hline Gene [GenBank number] & 24 hours $R Q\left(R_{\text {Max/Min }}\right)$ & 24 hours $R Q\left(R_{\operatorname{Max} / \operatorname{Min}}\right)$ & $\mathrm{RQ}$ \\
\hline GADD $/ 53$ [S40706] & $0.64(1.55 / 0.27)$ & $0.56(0.74 / 0.43)$ & 4.55 \\
\hline IL-8 [M28I30] & $0.17(0.3210 .09)$ & $0.14(0.16 / 0.13)$ & 1056.07 \\
\hline SMAD6 [ㄴ599|4] & $0.74(0.83 / 0.66)$ & $0.78(0.87 / 0.69)$ & 14.56 \\
\hline COL5AI [D90279] & $1.75(2.00 / 1.53)$ & $2.65(3.5 I / 2.0 I)$ & 2.28 \\
\hline HEFI [Lي4382I] & $3.26(3.50 / 3.05)$ & $3.37(3.99 / 2.85)$ & 3.93 \\
\hline TLR4 [U93091] & $0.80(1.05 / 0.61)$ & $0.96(1.07 / 0.87)$ & 3.98 \\
\hline$E T-I[105008]$ & $3.27(3.47 / 3.09)$ & $3.06(3.52 / 2.66)$ & 3.87 \\
\hline CARP $[\underline{\mathrm{X} 83703}]$ & $0.89(1.21 / 0.65)$ & $\mathrm{I} .32(2.4 \mathrm{I} / 0.72)$ & 4.29 \\
\hline $\mathrm{HPTP} \eta[\mathrm{D} 3778 \mathrm{I}]$ & $0.94(1.12 / 0.79)$ & $1.14(1.62 / 0.80)$ & 2.08 \\
\hline IDI $[\underline{\underline{S 78825}}]$ & $0.72(0.79 / 0.65)$ & $0.91(1.07 / 0.78)$ & 6.56 \\
\hline BMP6 [M603।5] & $2.44(2.72 / 2.19)$ & $2.60(2.82 / 2.39)$ & 4.26 \\
\hline ALK5 [LII1695] & $1.07(1.16 / 0.98)$ & $1.43(1.64 / 1.25)$ & 1.36 \\
\hline$T \beta R I I[\mathrm{M} 85079]$ & $0.97(1.10 / 0.85)$ & $0.99(1.04 / 0.94)$ & 1.26 \\
\hline Endoglin [j0548I] & $1.04(1.22 / 0.88)$ & $1.22(1.29 / 1.16)$ & 2.36 \\
\hline c-myc [ $\underline{\mathrm{V} 00568}]$ & $1.32(1.71 / 1.02)$ & $1.47(1.88 / 1.16)$ & 1.45 \\
\hline$A L K I[\underline{\underline{L} I 7075]} \mathrm{ABI}$ assay & $1.01(1.23 / 0.83)$ & $1.23(1.45 / 1.04)$ & 1.40 \\
\hline ALKI [LI $\underline{\underline{17075}}]$ own assay & 1.26 & 1.01 & $5079.92 *$ \\
\hline
\end{tabular}

*, ectopic expression

Several genes showed a clear concentration dependent biphasic effect. Low TGF- $\beta 1$ concentrations $(0.25 \mathrm{ng} / \mathrm{ml}, 0.5$ $\mathrm{ng} / \mathrm{ml}$ ) increased the expression of COL5A1, HEF1, HPTP $\eta, D N A J B 1 / H S P 40$ and ALK1 whereas higher concentrations $(1 \mathrm{ng} / \mathrm{ml}, 4 \mathrm{ng} / \mathrm{ml})$ reduced expression, which was most obvious at $4 \mathrm{ng} / \mathrm{ml}$ (Figure 1). A second group of genes, $I L-8, G A D D 153$ and $c-m \gamma c$, were down-regulated at all TGF- $\beta 1$ concentrations. For a third group of genes, $T L R 4$ and $E T-1$, reduced expression was only observed at $4 \mathrm{ng} / \mathrm{ml}$ TGF- $\beta 1$ and the expression of CARP was not changed by any of the TGF- $\beta 1$ concentrations. SMAD6 showed a surprising expression pattern, being up-regulated at the intermediate TGF- $\beta 1$ concentration of $1 \mathrm{ng} / \mathrm{ml}$ but was otherwise unaffected by any other concentration. We also tested for MGSA but were unable to detect endogenous expression in HUVECs.

\section{Discussion}

The aim of this study was to identify genes that are regulated by ALK1 signalling in endothelial cells. We were able to identify 34 genes by Affymetrix GeneChip ${ }^{\mathrm{TM}}$ and qRTPCR analysis that were up-regulated in at least two out of three independent experiments in HMEC-1 cells after 24 hours (Table 4) and 15 genes identified by GeneChip ${ }^{\text {тм }}$ analysis being regulated after 4 hours (Table 5). Those genes regulated after 4 hours are considered to be early response genes and therefore are most likely direct targets of ALK1 signalling, whereas the genes identified after 24 hours are either late response genes or are indirectly effected by ALK1 signalling. Nevertheless, abrogated or reduced ALK1 signalling would affect the expression of early and late response genes as well as indirectly regulated genes.

HHT is a vascular disorder of localized imbalanced angiogenesis [38] caused by mutations in ALK1 or endoglin, which implies that ALK1 signalling regulates angiogenesis related genes. Indeed, several of the identified genes in our study are reported to be involved in angiogenesis, tumor angiogenesis and arteriogenesis, i.e. IL-8 [39], ET-1 [40], CARP [41], HPTP $\eta$ [42], ID1 [43,44], MGSA [45], SMAD7 [46], HO-1 [47,48], RHOB [49], PTHLH [50,51], SERPINH1/HSP47 [52], JAG1 [53], GNA13 [54] and TEAD4 [55]. Animal studies for some of these genes showed that gene deletion causes embryonic lethality in mice that is accompanied by, or the result of, vascular defects, in part similar to those seen in HHT mice models.

HРТP $\eta$ homozygous mutant mice died before embryonic day 11.5 with vascularisation failure marked by growth 

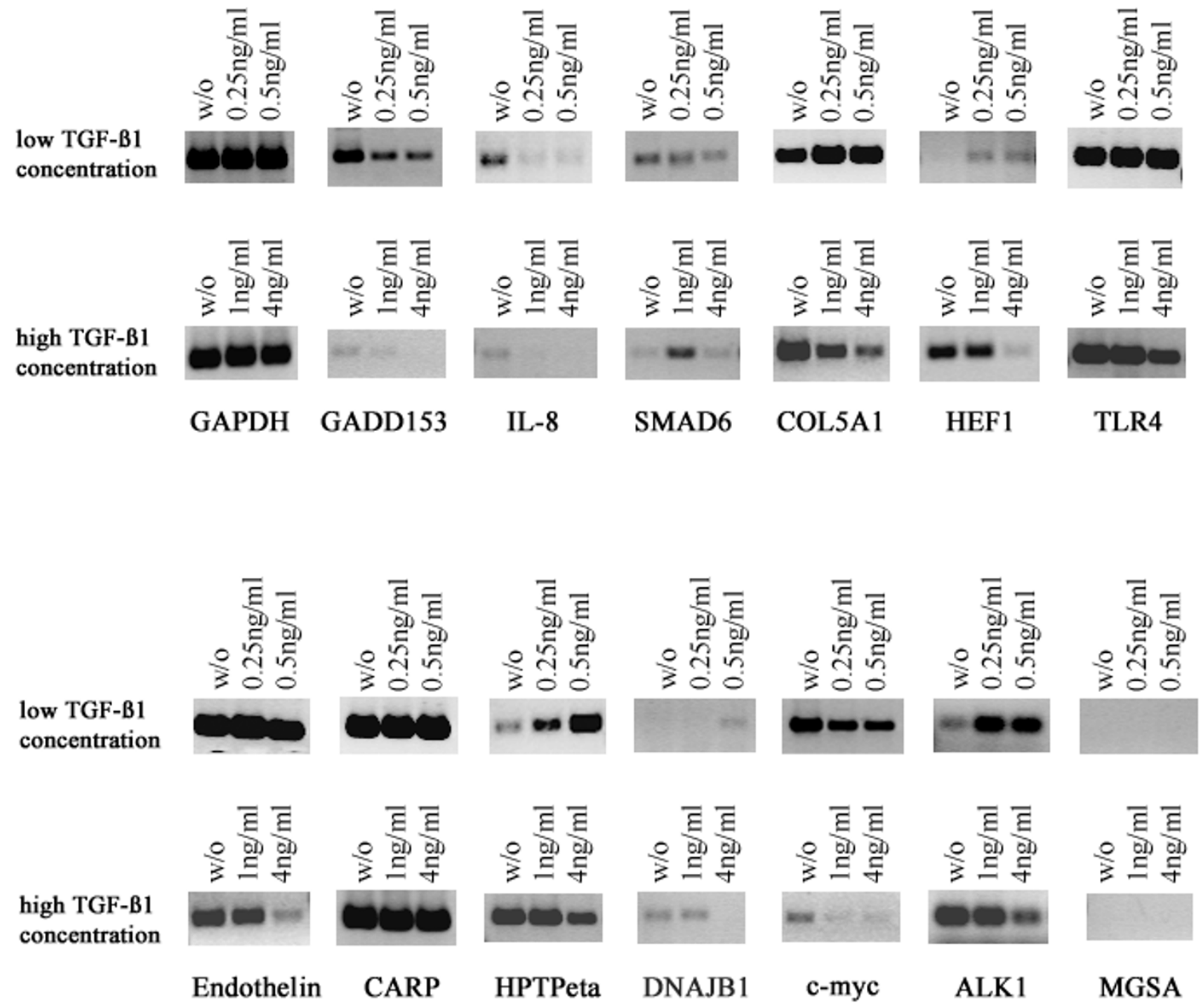

Figure I

TGF- $\beta$ I regulated gene expression in primary HUVECs. Primary HUVECs were treated for 16 hours with different TGF- $\beta$ I concentrations as indicated. Subsequently, RNA was isolated and gene expression for a set of genes was investigated by semi-quantitative RT-PCR. Expression levels for the GAPDH gene served as an internal control.

retardation, disorganized vascular structures with a notable lack of endoglin expression, an increase in endothelial cell numbers and mitotic activity. Mutant embryos showed homogeneously enlarged primitive vessels defective in vascular remodelling and branching, similar to endoglin-deficient embryos [42]. ID1 activates endothelial cell proliferation and migration, represses the transcription of the angiogenesis inhibitor thrombospondin1 , and ID1 expression can be induced by VEGF and TGF$\beta 1$ [43]. RHOB null mice showed a retarded vascular development characterized by altered sprout morphology. Depletion of RhoB in neonatal rats is associated with apoptosis in the sprouting endothelial cells of newly forming vessels and similarly, in primary endothelial cell culture models RhoB anti-sensense RNA treatment led to apoptosis and failure in tube formation [49]. Jagged1 knock-out mice are embryonically lethal with vascular remodelling defects [56]. Mutations in Jagged1 cause the Alagille syndrome (AGS) a dominantly inherited multisystem disorder. Intracranial bleeding is a recognized complication and a cause of mortality in AGS due to intracranial vessel abnormalities. There is a body of evidence supporting a role for Jagged 1 and the Notch signalling pathway in vascular development, i.e. arterial-venous 
differentiation [57]. TGF- $\beta 1$ regulates the expression of extracellular matrix (ECM) proteins.

We identified two genes, SERPINH1/HSP47 and COL5A1, to be up-regulated by ALK1 that can be directly linked to the ECM. The heat shock protein hsp47 is involved in the maturation of the ECM protein type I collagen, both being induced by TGF- $\beta 1$ [58]. COL5A1 expression in osteoblasts and vascular smooth muscle cells is induced by TGF$\beta 1[59,60]$ and haplo-insufficiency leads to the heritable connective-tissue disorder Ehlers-Danlos syndrome that is characterized by an altered collagen-fibrillar structure of the dermis, joints, eyes and blood vessels [61]. COL5A1 /- mice are embryonially lethal around day E10 and death is associated with pooling of blood in the yolk sac, suggesting an insufficient wall integrity to maintain a functioning yolk sac [62]. Mis-expression of Smad7 gave rise to dilated large vessels in the developing chick limb and head, and development of intra and intervascular shunts were frequently observed [46]. It is noteworthy that the ALK1 early response gene TEAD4/RTEF-1 is a transcription factor that stimulates VEGF expression and thus promotes endothelial migration and tube formation [54].

The cumulative developmental and biological data for the above described proteins and the fact that their genes are ALK1-regulated suggests that ALK1 is part of an interdependent network in vascular homeostasis. This might explain the vascular defects observed in HHT patients and HHT mice models. Many of these genes may be potential candidates in the search for HHT modifier genes. Thus, it would be important now to investigate the expression profile of these genes in the HHT endoglin and ALK1 mice models as well as in HHT patients. Furthermore, the ALK1-response genes endothelin (ET-1), heme oxygenase (HO-1) and BMP6 might also be involved in other vascular disorders. For example, patients with ALK1 mutations were reported with overlapping symptoms for HHT and primary pulmonary hypertension [63] a disorder effecting endothelial as well as smooth muscle cells. Endothelin and heme oxygenase play a role in vascular tone regulation $[64,65]$ and BMP6 is involved in vascular smooth muscle cell differentiation and being an antagonist of TGF- $\beta 1$ [66].

ALK1 is a TGF- $\beta 1$ receptor. We therefore performed a literature search to see which one of the ALK1 regulated genes were reported to be TGF- $\beta 1$ response genes. We found reports for 19 genes to be regulated by TGF- $\beta 1$ (Table 4 and 5). Furthermore, our sqRT-PCR results for primary HUVECs (Figure 1) demonstrate that GADD153, $H P T P \eta, T L R 4$ and DNAJB1 expression is also regulated by TGF- $\beta 1$ adding these genes to the list of TGF- $\beta 1$ response genes while the remaining genes might be new target genes of TGF- $\beta$ s or BMPs. In addition, expression of sev- eral ALK1-response genes in primary HUVECs are regulated by TGF- $\beta 1$ in a concentration dependent bi-phasic way (Figure 1), being up-regulated at lower TGF- $\beta 1$ concentrations and down-regulated at high concentrations. Such a TGF- $\beta$ dose dependent response mechanism for primary endothelial cells was reported previously [6], showing that low TGF- $\beta 1$ concentrations $(0.25 \mathrm{ng} / \mathrm{ml}$ and $0.5 \mathrm{ng} / \mathrm{ml}$ ) phosphorylated Smad1/5 and enhanced proliferation and migration mediated by ALK1, whereas high TGF- $\beta 1$ concentrations $(\geq 2.5 \mathrm{ng} / \mathrm{ml}$ ) had the opposite effect mediated by ALK5 due to phosphorylation of Smad2/3. Further experiments are currently under way to investigate how ALK1 might be involved in the bi-phasic activity of TGF- $\beta 1$ in regulating the here identified ALK1response genes. In addition, we show to our knowledge for the first time, that $A L K 1$ expression in primary HUVECs is regulated by TGF- $\beta 1$ (Figure 1 ).

We observed distinct gene expression responses upon ALK1 QD signalling among three different endothelial cell types (Table 6, summarized in Table 8), two established endothelial cell lines (HMEC-1, ECRF24) and primary endothelial cells (HUVECs). Cell type differences within the endothelial lineage were also observed for TGF- $\beta 1$ induced gene expression in primary HUVECs and HMEC1 cells (summarized in Table 8). TGF- $\beta 1$ regulated gene expression in HMEC-1 cells did not follow the expression pattern as seen for several genes in primary HUVECs. For example, COL5A1 and HEF1 were up-regulated in HMEC1 cells at low and high TGF- $\beta 1$ concentrations, but in HUVECs these genes followed a dose dependent expression pattern. This difference between different endothelial cell types might explain why there is only minimal overlap between our list of ALK1 regulated genes and previously published reports.

Lamouille and colleagues analysed ALK1 induced gene expression of AdALK1 1 D infected primary dermal microvascular endothelial cells after 15 hours [30], but there is no overlap regarding the expression profile with our study, and this was despite the HMEC-1 cell line being derived from dermal microvascular endothelial cells. In a study by Ota et al. [35], primary HUVECs were used to establish an ALK1 regulated expression profile 48 hours after AdALK1 QD infection and only the increased expression for SMAD6, SMAD7, ID1, ID2 and endoglin agrees with our study. The greatest agreement can be found with a recent analysis by Wu et al. [67]. Here, AdALK1QD infected human lung microvascular endothelial cells were used to investigate ALK1 regulated gene expression comparable to the expression profile initiated after 4 hour TGF- $\beta 1$ treatment as stated by the authors. The authors report increased expression for GADD153, HEF1, DNAJB1, HO-1, SMAD7, CRYAB, HERPUD1, LENG4 and SERPINH1, like in our study but they did not find 
Table 8: Overview of constitutively active ALKI and TGF- $\beta$ I regulated gene expression in different endothelial cell types.

\begin{tabular}{|c|c|c|c|c|c|c|c|}
\hline \multirow[b]{2}{*}{ Gene } & \multicolumn{3}{|c|}{ ALKIQD regulated gene expression } & \multicolumn{2}{|c|}{ low TGF- $\beta$ I conc. $(\leq 0.5 \mathrm{ng} / \mathrm{ml})$} & \multicolumn{2}{|c|}{ high TGF- $\beta$ I conc. $(\geq \mathrm{I} \mathrm{ng} / \mathrm{ml})$} \\
\hline & HMEC-I & HUVEC & ECRF24 & HMEC-I & HUVEC & HMEC-I & HUVEC \\
\hline GADD $/ 53$ & up & up & up & down & down & down & down \\
\hline IL-8 & up & up & up & down & down & down & down \\
\hline SMAD6 & up & up & up & down & - & down & up \\
\hline COL5AI & up & up & - & up & up & up & down \\
\hline HEFI & up & - & up & up & up & up & down \\
\hline TLR4 & up & up & - & down & - & - & down \\
\hline$E T-I$ & up & up & - & up & - & up & down \\
\hline CARP & up & up & - & down & - & - & - \\
\hline HPTP $\eta$ & up & - & - & - & up & - & down \\
\hline$I D I$ & up & up & up & down & $\mathrm{nt}$ & - & $\mathrm{nt}$ \\
\hline BMP6 & up & - & - & up & $\mathrm{nt}$ & up & nt \\
\hline ALK5 & - & down & - & - & $\mathrm{nt}$ & - & $\mathrm{nt}$ \\
\hline$T \beta R I I$ & - & - & down & down & $\mathrm{nt}$ & - & $\mathrm{nt}$ \\
\hline Endoglin & up & up & - & - & $\mathrm{nt}$ & - & $\mathrm{nt}$ \\
\hline c-myc & - & - & - & up & down & up & down \\
\hline ALKI & - & - & - & - & up & - & down \\
\hline
\end{tabular}

up, up-regulated expression; down, down-regulated expression; -, unchanged expression; nt, not tested

increased expression for endoglin, SMAD6 or ID1 or ID2 as we and Ota et al. observed. However, several other genes including TLR4, endoglin, JAG1, CD155 and KPNA3 which we found to be increased by ALK1 were instead induced by TGF- $\beta 1$ in the study by Wu et al. Furthermore, they showed that the profiles of genes regulated by TGF- $\beta 1$, ALK1 and ALK5 in lung microvascular endothelial cells are distinct from each other, although some genes are regulated by all of them. This is similar to our data in that there is a difference in TGF- $\beta$ induced signalling and constitutively active ALK1 signalling in HMEC-1 cells (Table 7, summarized in Table 8) and HUVECs. In HUVECs, constitutively active ALK1 increased IL-8, GADD153 and $C A R P$ expression that were either repressed by TGF- $\beta 1$ or unchanged (Figure 1). How can this be explained? The observed disparities might be due to ligand mediated transient responses versus the sustained responses owing to a constitutively active receptor. Signal intensity and duration are important factors in signal specificity. It is also possible that cell type dependent TGF- $\beta 1$ acts through Smad-dependent and Smad-independent pathways. Nevertheless, it can not be excluded that further ALK1 ligands like TGF- $\beta 3$ or may be BMP9 [68] exist that initiate a different gene profile than TGF- $\beta 1$. In addition, it is also possible that ligand independent $\mathrm{ALK1} \mathrm{QD}^{\mathrm{Q}}$ regulated gene expression in endothelial cells might partly reflect ALK1-specific responses (i.e. REST, NFIB, TEAD4, NF2, HEF1) for other cell types like smooth muscle cells or neuronal cells [69].

\section{Conclusion}

In conclusion, we have identified new ALK1 as well as TGF- $\beta 1$ response genes. Several of those are involved in the different phases of angiogenesis. Being down-stream of the ALK1 signalling pathway the expression of these genes would be affected by ALK1 mutations suggesting that these genes might be involved in the development of HHT. In addition, we showed that ligand induced receptor signalling and subsequent gene expression can be different from gene expression induced by constitutively active receptor signalling. Therefore, the gene expression results obtained from studies with constitutively active receptors like ALK1 ${ }^{\mathrm{QD}}$ help to identify new target genes but the results may not necessarily reflect the ligand activated gene expression profile. This needs to be established in further assays.

\section{Abbreviations}

ALK, activin receptor-like kinase; $\mathrm{BMP}$, bone morphogenetic protein; conc., concentration; FCS, fetal calf serum; HHT, hereditary hemorrhagic telangiectasia; HMEC, human microvascular endothelial cell; HUVEC, human umbilical vein endothelial cell; MOI, multiplicity of infection; qRT-PCR, quantitative real-time-polymerase chain reaction; RT, reverse transcription; sqRT-PCR, semi quantitative RT-PCR; TGF, transforming growth factor.

\section{Competing interests}

The author(s) declare that they have no competing interests. 


\section{Authors' contributions}

AL conceived, designed, coordinated and participated in the experiments of the study and drafted the manuscript. FS carried out the qRT-PCR and statistical analysis, HKD carried out the Affymetrix GeneChip ${ }^{\mathrm{TM}}$ experiments and statistical analysis, GK-L generated the recombinant Adenoviruses, $\mathrm{MH}$ participated in the coordination of the study and helped to draft the manuscript, PJRD participated in the coordination of the qRT-PCR and helped to draft the manuscript, DAM participated in the design and coordination of the study, JG participated in the design and coordination of the study and helped to draft the manuscript. All authors read and approved the final manuscript.

\section{Acknowledgements}

This work was supported by NIH Grant 5ROI-HL49I7I-I 3 (to D.A.M.), by the British Heart Foundation (project grant no.PG/02/100/I 4280) (to J.G.) and by the ZAF-Biotechnologie Zukunftsoffensive Baden-Württemberg, Germany (to A.L., M.H.).

\section{References}

I. Massague J, Blain SW, Lo RS: TGFbeta signaling in growth control, cancer, and heritable disorders. Cell 2000, 103:295-309.

2. ten Dijke P, Hill CS: New insights into TGF-beta-Smad signalling. Trends Biochem Sci 2004, 29:265-273.

3. Blobe GC, Schiemann WP, Lodish HF: Role of transforming growth factor beta in human disease. N Engl J Med 2000, 342:1350-1358.

4. Shi $Y$, Massague J: Mechanisms of TGF-beta signaling from cell membrane to the nucleus. Cell 2003, I I3:685-700.

5. Pepper MS: Transforming growth factor-beta: vasculogenesis, angiogenesis, and vessel wall integrity. Cytokine Growth Factor $\operatorname{Rev}$ 1997, 8:21-43.

6. Goumans MJ, Valdimarsdottir G, Itoh S, Rosendahl A, Sideras P, ten Dijke P: Balancing the activation state of the endothelium via two distinct TGF-beta type I receptors. Embo J 2002, 21:1743-1753.

7. Pepper MS, Vassalli JD, Orci L, Montesano R: Biphasic effect of transforming growth factor-beta $I$ on in vitro angiogenesis. Exp Cell Res 1993, 204:356-363.

8. Gajdusek CM, Luo Z, Mayberg MR: Basic fibroblast growth factor and transforming growth factor beta-I: synergistic mediators of angiogenesis in vitro. J Cell Physiol 1993, I 57:133-144.

9. van den Driesche S, Mummery CL, Westermann CJ: Hereditary hemorrhagic telangiectasia: an update on transforming growth factor beta signaling in vasculogenesis and angiogenesis. Cardiovasc Res 2003, 58:20-31.

10. Marchuk DA, Lux A: Hereditary Hemorrhagic Telangiectasia. In The Metabolic \& Molecular Bases of Inherited Disease Volume IV. 8th edition. Edited by: Scriver CRBALVDSWS. , McGraw-Hill Medical Publishing Division; 2001:5419 -5543I.

II. Marchuk DA, Srinivasan S, Squire TL, Zawistowski JS: Vascular morphogenesis: tales of two syndromes. Hum Mol Genet 2003, I 2 Spec No I:R97- I I 2.

12. Braverman IM, Keh A, Jacobson BS: Ultrastructure and threedimensional organization of the telangiectases of hereditary hemorrhagic telangiectasia. J Invest Dermatol 1990, 95:422-427.

13. McAllister KA, Grogg KM, Johnson DW, Gallione CJ, Baldwin MA, Jackson CE, Helmbold EA, Markel DS, McKinnon WC, Murrell J, McCormick K, Pericak-Vance MA, Heutink P, Oostra BA, Haitjema T, Westerman CJJ, Porteous ME, Guttmacher AE, Letarte M, Marchuk DA: Endoglin, a TGF-beta binding protein of endothelial cells, is the gene for hereditary haemorrhagic telangiectasia type I. Nat Genet 1994, 8:345-35I.

14. Johnson DW, Berg JN, Baldwin MA, Gallione CJ, Marondel I, Yoon SJ, Stenzel TT, Speer M, Pericak-Vance MA, Diamond A, Guttmacher AE, Jackson CE, Attisano L, Kucherlapati R, Porteous ME, Marchuk DA: Mutations in the activin receptor-like kinase I gene in hered- itary haemorrhagic telangiectasia type 2. Nat Genet 1996, 13:189-195.

15. Gallione CJ, Repetto GM, Legius E, Rustgi AK, Schelley SL, Tejpar S, Mitchell G, Drouin E, Westermann CJ, Marchuk DA: A combined syndrome of juvenile polyposis and hereditary haemorrhagic telangiectasia associated with mutations in MADH4 (SMAD4). Lancet 2004, 363:852-859.

16. Cheifetz S, Bellon T, Cales C, Vera S, Bernabeu C, Massague J, Letarte $M$ : Endoglin is a component of the transforming growth factor-beta receptor system in human endothelial cells. J Biol Chem 1992, 267:19027-19030.

17. Letamendia A, Lastres P, Botella LM, Raab U, Langa C, Velasco B, Attisano L, Bernabeu C: Role of endoglin in cellular responses to transforming growth factor-beta. A comparative study with betaglycan. J Biol Chem 1998, 273:330 II-330I9.

18. Lux A, Attisano L, Marchuk DA: Assignment of transforming growth factor betal and beta 3 and a third new ligand to the type I receptor ALK-I. J Biol Chem 1999, 274:9984-9992.

19. Macias-Silva M, Hoodless PA, Tang SJ, Buchwald M, Wrana JL: Specific activation of SmadI signaling pathways by the BMP7 type I receptor, ALK2. J Biol Chem 1998, 273:25628-25636.

20. Chen YG, Massague J: Smad I recognition and activation by the ALKI group of transforming growth factor-beta family receptors. J Biol Chem 1999, 274:3672-3677.

21. Bourdeau A, Dumont DJ, Letarte M: A murine model of hereditary hemorrhagic telangiectasia. J Clin Invest 1999, 104:1343-135|.

22. Arthur HM, Ure J, Smith AJ, Renforth G, Wilson DI, Torsney E, Charlton R, Parums DV, Jowett T, Marchuk DA, Burn J, Diamond AG: Endoglin, an ancillary TGFbeta receptor, is required for extraembryonic angiogenesis and plays a key role in heart development. Dev Biol 2000, 217:42-53.

23. Li DY, Sorensen LK, Brooke BS, Urness LD, Davis EC, Taylor DG, Boak BB, Wendel DP: Defective angiogenesis in mice lacking endoglin. Science 1999, 284:1534-1537.

24. Oh SP, Seki T, Goss KA, Imamura T, Yi Y, Donahoe PK, Li L, Miyazono K, ten Dijke P, Kim S, Li E: Activin receptor-like kinase I modulates transforming growth factor-beta I signaling in the regulation of angiogenesis. Proc Natl Acad Sci U S A 2000, 97:2626-263I.

25. Srinivasan S, Hanes MA, Dickens T, Porteous ME, Oh SP, Hale LP, Marchuk DA: A mouse model for hereditary hemorrhagic telangiectasia (HHT) type 2. Hum Mol Genet 2003, 12:473-482.

26. Torsney E, Charlton R, Diamond AG, Burn J, Soames JV, Arthur HM: Mouse model for hereditary hemorrhagic telangiectasia has a generalized vascular abnormality. Circulation 2003, 107:1653-1657.

27. Lebrin F, Goumans MJ, Jonker L, Carvalho RL, Valdimarsdottir G, Thorikay M, Mummery C, Arthur HM, ten Dijke P: Endoglin promotes endothelial cell proliferation and TGF-beta/ALK I signal transduction. Embo J 2004, 23:40I8-4028.

28. Blanco FJ, Santibanez JF, Guerrero-Esteo M, Langa C, Vary CP, Bernabeu C: Interaction and functional interplay between endoglin and ALK-I, two components of the endothelial transforming growth factor-beta receptor complex. J Cell Physiol 2005, 204:574-584.

29. Goumans MJ, Valdimarsdottir G, Itoh S, Lebrin F, Larsson J, Mummery C, Karlsson S, ten Dijke P: Activin receptor-like kinase (ALK) I is an antagonistic mediator of lateral TGFbeta/ALK5 signaling. Mol Cell 2003, 12:817-828.

30. Ades EW, Candal FJ, Swerlick RA, George VG, Summers S, Bosse DC, Lawley TJ: HMEC-I: establishment of an immortalized human microvascular endothelial cell line. J Invest Dermatol 1992, 99:683-690.

3I. Fontijn R, Hop C, Brinkman HJ, Slater R, Westerveld A, van Mourik JA, Pannekoek H: Maintenance of vascular endothelial cell-specific properties after immortalization with an amphotrophic replication-deficient retrovirus containing human papilloma virus 16 E6/E7 DNA. Exp Cell Res 1995, 216:199-207.

32. Hardy S, Kitamura M, Harris-Stansil T, Dai Y, Phipps ML: Construction of adenovirus vectors through Cre-lox recombination. J Virol 1997, 71: 1842-1849.

33. [[http://www.affymetrix.com/index.affx]]

34. [[http://www.data.cgt.duke.edu/Andreas.php]].

35. Ota T, Fujii M, Sugizaki T, Ishii M, Miyazawa K, Aburatani H, Miyazono $\mathrm{K}$ : Targets of transcriptional regulation by two distinct type 
I receptors for transforming growth factor-beta in human umbilical vein endothelial cells. J Cell Physiol 2002, 193:299-3 I8.

36. Lamouille S, Mallet C, Feige JJ, Bailly S: Activin receptor-like kinase $\mathrm{I}$ is implicated in the maturation phase of angiogenesis. Blood 2002, 100:4495-450I.

37. Morgan TE, Rozovsky I, Sarkar DK, Young-Chan CS, Nichols NR, Laping NJ, Finch CE: Transforming growth factor-beta I induces transforming growth factor-betal and transforming growth factor-beta receptor messenger RNAs and reduces complement ClqB messenger RNA in rat brain microglia. Neuroscience 2000, I0I:313-32I.

38. Sadick H, Riedel F, Naim R, Goessler U, Hormann K, Hafner M, Lux A: Patients with hereditary hemorrhagic telangiectasia have increased plasma levels of vascular endothelial growth factor and transforming growth factor-betal as well as high ALK I tissue expression. Haematologica 2005, 90:818-828.

39. Belperio JA, Keane MP, Arenberg DA, Addison CL, Ehlert JE, Burdick MD, Strieter RM: CXC chemokines in angiogenesis. J Leukoc Biol 2000, 68: I-8.

40. Bagnato A, Spinella F: Emerging role of endothelin-I in tumor angiogenesis. Trends Endocrinol Metab 2003, I 4:44-50.

41. Boengler K, Pipp F, Fernandez B, Ziegelhoeffer T, Schaper W, Deind $\mathrm{E}$ : Arteriogenesis is associated with an induction of the cardiac ankyrin repeat protein (carp). Cardiovasc Res 2003, 59:573-581.

42. Takahashi T, Takahashi K, St John PL, Fleming PA, Tomemori T, Watanabe T, Abrahamson DR, Drake C], Shirasawa T, Daniel TO: A mutant receptor tyrosine phosphatase, CDI48, causes defects in vascular development. Mol Cell Biol 2003, 23:|8|7-|83|.

43. Sakurai D, Tsuchiya N, Yamaguchi A, Okaji Y, Tsuno NH, Kobata T, Takahashi K, Tokunaga K: Crucial role of inhibitor of DNA binding/differentiation in the vascular endothelial growth factorinduced activation and angiogenic processes of human endothelial cells. J Immunol 2004, I 73:580 I-5809.

44. Volpert OV, Pili R, Sikder HA, Nelius T, Zaichuk T, Morris C, Shiflett $\mathrm{CB}$, Devlin MK, Conant K, Alani RM: Id I regulates angiogenesis through transcriptional repression of thrombospondin-I. Cancer Cell 2002, 2:473-483.

45. Haghnegahdar H, Du J, Wang D, Strieter RM, Burdick MD, Nanney LB, Cardwell N, Luan J, Shattuck-Brandt R, Richmond A: The tumorigenic and angiogenic effects of MGSA/GRO proteins in melanoma. J Leukoc Biol 2000, 67:53-62.

46. Vargesson N, Laufer E: Smad7 misexpression during embryonic angiogenesis causes vascular dilation and malformations independently of vascular smooth muscle cell function. Dev Biol 200I, 240:499-516.

47. Bussolati B, Ahmed A, Pemberton H, Landis RC, Di Carlo F, Haskard DO, Mason JC: Bifunctional role for VEGF-induced heme oxygenase- $I$ in vivo: induction of angiogenesis and inhibition of leukocytic infiltration. Blood 2004, 103:76I-766.

48. Dulak J, Loboda A, Zagorska A, Jozkowicz A: Complex role of heme oxygenase-I in angiogenesis. Antioxid Redox Signal 2004, 6:858-866.

49. Adini I, Rabinovitz I, Sun JF, Prendergast GC, Benjamin LE: RhoB controls Akt trafficking and stage-specific survival of endothelial cells during vascular development. Genes Dev 2003, I 7:272I-2732.

50. Bakre MM, Zhu Y, Yin H, Burton DW, Terkeltaub R, Deftos LJ, Varner JA: Parathyroid hormone-related peptide is a naturally occurring, protein kinase A-dependent angiogenesis inhibitor. Nat Med 2002, 8:995-1003.

51. Akino K, Ohtsuru A, Kanda K, Yasuda A, Yamamoto T, Akino Y, Naito S, Kurokawa M, Iwahori N, Yamashita S: Parathyroid hormone-related peptide is a potent tumor angiogenic factor. Endocrinology 2000, 141:43 I3-4316.

52. Nikitakis NG, Rivera H, Lopes MA, Siavash $\mathrm{H}$, Reynolds MA, Ord RA Sauk JJ: Immunohistochemical expression of angiogenesisrelated markers in oral squamous cell carcinomas with multiple metastatic lymph nodes. Am \& Clin Pathol 2003, I 1 9:574-586.

53. Shawber C], Kitajewski J: Notch function in the vasculature: insights from zebrafish, mouse and man. Bioessays 2004, 26:225-234.

54. Ruppel KM, Willison D, Kataoka H, Wang A, Zheng YW, Cornelissen I, Yin L, Xu SM, Coughlin SR: Essential role for Galphal3 in endothelial cells during embryonic development. Proc Nat Acad Sci U S A 2005, 102:828I-8286.

55. Shie JL, Wu G, Wu J, Liu FF, Laham RJ, Oettgen P, Li J: RTEF-I, a novel transcriptional stimulator of vascular endothelial growth factor in hypoxic endothelial cells. J Biol Chem 2004, 279:25010-25016.

56. Xue Y, Gao X, Lindsell CE, Norton CR, Chang B, Hicks C, GendronMaguire M, Rand EB, Weinmaster G, Gridley T: Embryonic lethality and vascular defects in mice lacking the Notch ligand Jagged I. Hum Mol Genet I999, 8:723-730.

57. Kamath BM, Spinner NB, Emerick KM, Chudley AE, Booth C, Piccoli DA, Krantz ID: Vascular anomalies in Alagille syndrome: a significant cause of morbidity and mortality. Circulation 2004, 109:1354-1358.

58. Martelli-Junior H, Cotrim P, Graner E, Sauk J], Coletta RD: Effect of transforming growth factor-betal, interleukin-6, and interferon-gamma on the expression of type I collagen, heat shock protein 47, matrix metalloproteinase (MMP)-I and MMP-2 by fibroblasts from normal gingiva and hereditary gingival fibromatosis. J Periodontol 2003, 74:296-306.

59. Kahai $S$, Vary $C P$, Gao $Y$, Seth A: Collagen, type V, alphal (COL5AI) is regulated by TGF-beta in osteoblasts. Matrix Biol 2004, 23:445-455.

60. Lawrence R, Hartmann DJ, Sonenshein GE: Transforming growth factor beta I stimulates type $\mathbf{V}$ collagen expression in bovine vascular smooth muscle cells. J Biol Chem 1994, 269:9603-9609.

61. Wenstrup RJ, Florer JB, Willing MC, Giunta C, Steinmann B, Young F, Susic M, Cole WG: COL5AI haploinsufficiency is a common molecular mechanism underlying the classical form of EDS. Am J Hum Genet 2000, 66: 1766-1776.

62. Wenstrup RJ, Florer JB, Brunskill EW, Bell SM, Chervoneva I, Birk DE Type $\mathbf{V}$ collagen controls the initiation of collagen fibril assembly. J Biol Chem 2004, 279:5333I-53337.

63. Trembath RC: Mutations in the TGF-beta type I receptor, $A L K I$, in combined primary pulmonary hypertension and hereditary haemorrhagic telangiectasia, implies pathway specificity. J Heart Lung Transplant 200I, 20:175.

64. Humbert M, Morrell NW, Archer SL, Stenmark KR, MacLean MR, Lang IM, Christman BW, Weir EK, Eickelberg O, Voelkel NF, Rabinovitch $\mathrm{M}$ : Cellular and molecular pathobiology of pulmonary arterial hypertension. J Am Coll Cardiol 2004, 43: I3S-24S.

65. Chen YH, Yet SF, Perrella MA: Role of heme oxygenase-I in the regulation of blood pressure and cardiac function. Exp Biol Med (Maywood) 2003, 228:447-453.

66. King KE, lyemere VP, Weissberg PL, Shanahan CM: Kruppel-like factor 4 (KLF4/GKLF) is a target of bone morphogenetic proteins and transforming growth factor beta $I$ in the regulation of vascular smooth muscle cell phenotype. J Biol Chem 2003, 278: I |66I-II669.

67. Wu X, Ma J, Han JD, Wang N, Chen YG: Distinct regulation of gene expression in human endothelial cells by TGF-beta and its receptors. Microvasc Res 2006, 7I:12-19.

68. Brown MA, Zhao Q, Baker KA, Naik C, Chen C, Pukac L, Singh M, Tsareva T, Parice Y, Mahoney A, Roschke V, Sanyal I, Choe S: Crystal Structure of BMP-9 and Functional Interactions with Proregion and Receptors. J Biol Chem 2005, 280:25 I II-25 I I8.

69. Konig HG, Kogel D, Rami A, Prehn JH: TGF-\{beta\} I activates two distinct type I receptors in neurons: implications for neuronal NF-\{kappa\}B signaling. J Cell Biol 2005, I68:1077-1086.

70. Xie L, Law BK, Aakre ME, Edgerton M, Shyr Y, Bhowmick NA, Moses $\mathrm{HL}$ : Transforming growth factor beta-regulated gene expression in a mouse mammary gland epithelial cell line. Breast Cancer Res 2003, 5:R I 87-98.

7I. Shi Y, Reitmaier B, Regenbogen J, Slowey RM, Opalenik SR, Wolf E, Goppelt A, Davidson JM: CARP, a cardiac ankyrin repeat protein, is up-regulated during wound healing and induces angiogenesis in experimental granulation tissue. Am J Pathol 2005, 166:303-312.

72. Kumar NM, Rabadi NH, Sigurdson LS, Schunemann HJ, LwebugaMukasa JS: Induction of interleukin-I and interleukin-8 mRNAs and proteins by TGF beta $I$ in rat lung alveolar epithelial cells. J Cell Physiol 1996, 169:186-199.

73. Fong CY, Pang L, Holland E, Knox AJ: TGF-betal stimulates IL-8 release, COX-2 expression, and PGE(2) release in human airway smooth muscle cells. Am J Physiol Lung Cell Mol Physiol 2000, 279:L20I-7. 
74. Chen CC, Manning AM: TGF-beta I, IL- I 0 and IL-4 differentially modulate the cytokine-induced expression of IL-6 and IL-8 in human endothelial cells. Cytokine 1996, 8:58-65.

75. Rodriguez-Pascual F, Redondo-Horcajo M, Lamas S: Functional cooperation between Smad proteins and activator protein-I regulates transforming growth factor-beta-mediated induction of endothelin-I expression. Circ Res 2003, 92: I 288-I 295.

76. Ferguson CM, Schwarz EM, Puzas JE, Zuscik MJ, Drissi H, O'Keefe RJ: Transforming growth factor-betal induced alteration of skeletal morphogenesis in vivo. J Orthop Res 2004, 22:687-696.

77. Ning W, Song R, Li C, Park E, Mohsenin A, Choi AM, Choi ME: TGFbetal stimulates $\mathrm{HO}$-I via the $\mathbf{p} 38$ mitogen-activated protein kinase in A549 pulmonary epithelial cells. Am J Physiol Lung Cell Mol Physiol 2002, 283:LI094-102.

78. Zavadil J, Cermak L, Soto-Nieves N, Bottinger EP: Integration of TGF-beta/Smad and Jagged I/Notch signalling in epithelialto-mesenchymal transition. Embo J 2004, 23: I I55- I I65.

79. Lindemann RK, Nordheim A, Dittmer J: Interfering with TGFbeta-induced Smad3 nuclear accumulation differentially affects TGFbeta-dependent gene expression. Mol Cancer 2003, 2:20.

80. Kakonen SM, Selander KS, Chirgwin JM, Yin JJ, Burns S, Rankin WA Grubbs BG, Dallas M, Cui Y, Guise TA: Transforming growth factor-beta stimulates parathyroid hormone-related protein and osteolytic metastases via Smad and mitogen-activated protein kinase signaling pathways. J Biol Chem 2002 277:2457I-24578

8I. Schiffer M, Schiffer LE, Gupta A, Shaw AS, Roberts IS, Mundel P, Bottinger EP: Inhibitory smads and tgf-Beta signaling in glomerular cells. J Am Soc Nephrol 2002, I 3:2657-2666.

82. Wheeler AP, Ridley A): Why three Rho proteins? RhoA, RhoB, RhoC, and cell motility. Exp Cell Res 2004, 30 I:43-49.

83. Rius C, Smith JD, Almendro N, Langa C, Botella LM, Marchuk DA, Vary CP, Bernabeu C: Cloning of the promoter region of human endoglin, the target gene for hereditary hemorrhagic telangiectasia type I. Blood 1998, 92:4677-4690.

84. Zheng M, McKeown-Longo PJ: Regulation of HEFI expression and phosphorylation by TGF-beta I and cell adhesion. J Biol Chem 2002, 277:39599-39608.

85. Kumarapeli AR, Wang X: Genetic modification of the heart: chaperones and the cytoskeleton. J Mol Cell Cardiol 2004, 37:1097-1109.

86. Welge-Lussen $U$, Bloemendal H, Lutjen-Drecoll E: Transforming growth factor-beta: a growth factor inducing alpha B-crystallin expression in ciliary muscle cells. Graefes Arch Clin Exp Ophthalmol 2000, 238:993-997.

87. Zhao X, Ramsey KE, Stephan DA, Russell P: Gene and protein expression changes in human trabecular meshwork cells treated with transforming growth factor-beta. Invest Ophthalmol Vis Sci 2004, 45:4023-4034.

88. Battelino T, Miralles F, Krzisnik C, Scharfmann R, Czernichow P. TGF-beta activates genes identified by differential mRNA display in pancreatic rudiments. Pflugers Arch 2000, 439:R26-8.

89. Oda T, Ohka S, Nomoto A: Ligand stimulation of CDI55alpha inhibits cell adhesion and enhances cell migration in fibroblasts. Biochem Biophys Res Commun 2004, 3 I 9:1253-1264.

90. Feral CC, Nishiya N, Fenczik CA, Stuhlmann H, Slepak M, Ginsberg $\mathrm{MH}$ : CD98hc (SLC3A2) mediates integrin signaling. Proc Nat Acad Sci U S A 2005, 102:355-360.

9I. Fang X, Chen T, Tran K, Parker CS: Developmental regulation of the heat shock response by nuclear transport factor karyopherin-alpha3. Development 200I, I 28:3349-3358.

92. Zuccato C, Tartari M, Crotti A, Goffredo D, Valenza M, Conti L, Cataudella T, Leavitt BR, Hayden MR, Timmusk T, Rigamonti D, Cattaneo E: Huntingtin interacts with REST/NRSF to modulate the transcription of NRSE-controlled neuronal genes. Nat Genet 2003, 35:76-83.

93. Cheong A, Bingham AJ, Li J, Kumar B, Sukumar P, Munsch C, Buckley NJ, Neylon CB, Porter KE, Beech DJ, Wood IC: Downregulated REST transcription factor is a switch enabling critical potassium channel expression and cell proliferation. Mol Cell 2005, 20:45-52.

94. Steele-Perkins G, Plachez C, Butz KG, Yang G, Bachurski C), Kinsman SL, Litwack ED, Richards LJ, Gronostajski RM: The transcription factor gene $\mathbf{N}$ fib is essential for both lung maturation and brain development. Mol Cell Biol 2005, 25:685-698.
95. Richardson KS, Zundel W: The emerging role of the COP9 signalosome in cancer. Mol Cancer Res 2005, 3:645-653.

\section{Pre-publication history}

The pre-publication history for this paper can be accessed here:

http://www.biomedcentral.com/1471-2261/6/13/prepub
Publish with Bio Med Central and every scientist can read your work free of charge

"BioMed Central will be the most significant development for disseminating the results of biomedical research in our lifetime. "

Sir Paul Nurse, Cancer Research UK

Your research papers will be:

- available free of charge to the entire biomedical community

- peer reviewed and published immediately upon acceptance

- cited in PubMed and archived on PubMed Central

- yours - you keep the copyright
BioMedcentral 